\title{
Shoreline Hardening Affects Nekton Biomass, Size Structure, and Taxonomic Diversity in Nearshore Waters, with Responses Mediated by Functional Species Groups
}

\author{
Matthew S. Kornis ${ }^{1,2}$ • Donna M. Bilkovic ${ }^{3}$ - Lori A. Davias ${ }^{1} \cdot$ Steve Giordano $^{4}$ • \\ Denise L. Breitburg ${ }^{1}$
}

Received: 8 September 2016 / Revised: 5 January 2017 / Accepted: 10 January 2017 /Published online: 24 April 2017

(C) The Author(s) 2017, corrected publication 2019

\begin{abstract}
Coastal shoreline hardening is intensifying due to human population growth and sea level rise. Prior studies have emphasized shoreline-hardening effects on faunal abundance and diversity; few have examined effects on faunal biomass and size structure or described effects specific to different functional groups. We evaluated the biomass and size structure of mobile fish and crustacean assemblages within two nearshore zones (waters extending 3 and $16 \mathrm{~m}$ from shore) adjacent to
\end{abstract}

Communicated by Marianne Holmer

Electronic supplementary material The online version of this article (doi:10.1007/s12237-017-0214-5) contains supplementary material, which is available to authorized users.

Matthew S. Kornis

matthew_kornis@fws.gov

Donna M. Bilkovic

donnab@vims.edu

Lori A. Davias

ladavias@gmail.com

Steve Giordano

steve.giordano@noaa.gov

Denise L. Breitburg

breitburgd@si.edu

1 Smithsonian Environmental Research Center, P.O. Box 28, Edgewater, MD 21037, USA

2 Green Bay Fish and Wildlife Conservation Office, US Fish and Wildlife Service, 2661 Scott Tower Drive, New Franken, WI 54229, USA

3 Virginia Institute of Marine Science, College of William \& Mary, P.O. Box 1346, Gloucester Point, VA 23062, USA

4 Department of Commerce, NOAA National Marine Fisheries Service, Southeast Regional Office, 263 13th Avenue South, St. Petersburg, FL 33701, USA natural (native wetland; beach) and hardened (bulkhead; riprap) shorelines. Within $3 \mathrm{~m}$ from shore, the total fish/crustacean biomass was greatest at hardened shorelines, driven by greater water depth that facilitated access to planktivore (e.g., bay anchovy) and benthivore-piscivore (e.g., white perch) species. Small-bodied littoral-demersal species (e.g., Fundulus spp.) had greatest biomass at wetlands. By contrast, total biomass was comparable among shoreline types within $16 \mathrm{~m}$ from shore, suggesting the effect of shoreline hardening on fish biomass is largely within extreme nearshore areas immediately at the land/water interface. Shoreline type utilization was mediated by body size across all functional groups: small individuals $(\leq 60 \mathrm{~mm})$ were most abundant at wetlands and beaches, while large individuals $(>100 \mathrm{~mm}$ ) were most abundant at hardened shorelines. Taxonomic diversity analysis indicated natural shoreline types had more diverse assemblages, especially within $3 \mathrm{~m}$ from shore, although relationships with shoreline type were weak and sensitive to the inclusion/exclusion of crustaceans. Our study illustrates how shoreline hardening effects on fish/crustacean assemblages are mediated by functional group, body size, and distance from shore, with important applications for management.

Keywords Shoreline modification - Shoreline armoring · Habitat degradation · Fish $\cdot$ Crustaceans $\cdot$ Chesapeake Bay

\section{Introduction}

Estuaries and coasts are among the world's most ecologically productive ecosystems, providing numerous ecosystem services benefitting society (Lotze et al. 2006; Barbier et al. 2011). Dense human populations in coastal areas continue to rapidly increase (Crossett et al. 2004), making estuarine systems especially vulnerable to human-linked stressors (Halpern 
et al. 2008; Barbier et al. 2011). Among these stressors, shoreline hardening has gained notoriety for numerous adverse ecological effects (e.g., Dugan et al. 2011; Gittman et al. 2016a). Demand for shoreline hardening is driven by desire to protect coastal land from erosion, and as such, shoreline hardening will likely increase with global sea level rise (Rahmstorf 2007; Arkema et al. 2013) and increasing human populations in coastal areas (Crossett et al. 2004). Indeed, replacement of natural shoreline by hardened structures (e.g., bulkheads, seawalls, riprap revetments) is growing in coastal areas (Brody et al. 2008; Gittman et al. 2015) where natural shorelines including tidal wetlands have already incurred substantial losses (Lotze et al. 2006; Gedan et al. 2009; Barbier et al. 2011).

Until recently, available information on the ecological effects of shoreline hardening was limited (Seitz et al. 2006; Dugan et al. 2011). Over the last few years, however, numerous studies have described a suite of deleterious ecological effects. Fish (e.g., Toft et al. 2007; Bilkovic and Roggero 2008; Peterson and Lowe 2009; Kornis et al. 2017), invertebrates (e.g., Seitz et al. 2006; Bilkovic et al. 2006; Lowe and Peterson 2014), submerged vegetation (e.g., Patrick et al. 2014, 2016), and microbial communities (Tan et al. 2015) have all been shown to change over gradients of natural to altered shorelines. Shoreline hardening has also been linked to the expansion of nonindigenous plants (Vaselli et al. 2008; McCormick et al. 2010; Kettenring et al. 2015; Sciance et al. 2016) and animals (Glasby et al. 2006; Bulleri and Chapman 2010), an indirect but substantial effect. Many studies have focused on abundance and diversity patterns, and a recent meta-analysis of prior studies found $23 \%$ lower biodiversity and $45 \%$ lower organism abundance on bulkheads/seawalls relative to natural shorelines (Gittman et al. 2016a). Nevertheless, there remains an incomplete understanding of the response of fish and crustacean assemblages to shoreline hardening (Bilkovic \& Roggero 2008; Strayer et al. 2012). For example, very few studies have examined how faunal biomass and size structure might be affected by shoreline hardening, although such effects may be substantial and have important implications for coastal management.

Our goal was to describe how the biomass, size structure, and diversity of nearshore fish and crustacean communities differed among hardened (bulkhead and riprap revetment) and natural (wetland (native vegetation) and beach) shoreline types. We also sought to answer two fundamental questions about potential responses to shoreline type: (1) how do responses differ among species, and (2) how do responses differ within comparatively narrow and wide definitions of the land/ water interface? To answer question (1), we examined biomass, size structure, and taxonomic distinctness of all species and also examined biomass and size structure among three functional groups common to most estuarine systems. We elected to group species into functional groups such that inference from our results could more easily transfer from our study system (Chesapeake Bay) to other systems. To answer question (2), we examined responses within two distinct ecotone widths to differentiate between waters immediately adjacent to the land/water interface (within $3 \mathrm{~m}$ from shore) and waters farther out from shore (within $16 \mathrm{~m}$ from shore). This study considers nuances of faunal response to shoreline hardening not previously addressed in most of the literature and provides a number of considerations for coastal management.

\section{Methods}

\section{Site Selection and Study Design}

We examined patterns in fish and crustacean biomass density, taxonomic distinctness, and utilization of shoreline type by size class in 16 mesohaline subestuaries (average salinity of 4-14) of the middle and upper Chesapeake Bay (Fig. 1). Here, we define "subestuaries" as independent estuaries, each with their own watershed, that feed into and interact with the larger Chesapeake Bay estuarine system; each site cluster in Fig. 1 is from a unique subestuary. Sampling occurred at two natural (wetland and beach) and two hardened (bulkhead and riprap) shoreline types prevalent in estuarine systems. Shoreline types were not sampled in proportion to their prevalence in the subestuary but rather in equal numbers within each subestuary to achieve a balanced design. Sites were selected in a randomized block design, in which sites were blocked by subestuary of capture. Although subestuarine-scale variables are not addressed in this study, subestuaries were deliberately chosen to include both highly developed (urban or agricultural land) and predominantly forested watersheds as part of a larger study focusing on shallow-water fish abundance patterns with land cover (Kornis et al. 2017). Therefore, the subestuaries in this study are representative of a wide range of conditions prevalent in the Chesapeake Bay and in other coastal systems. All fishes (common and scientific names in Online Resource B) and environmental data were collected between 31 July and 23 September in 2008 (Rhode River only), 2010, 2011, and 2012. This time window was chosen to avoid spring seasonal effects on fish and crustacean abundances, which are rather strong in Chesapeake Bay due to spring migrations of ocean-spawning species (e.g., blue crab, Atlantic croaker, spot). Although there may be temporal effects on fish and crustacean abundances within our sampling time window, these are accounted for in our analysis by treating subestuary as a blocking variable, as all sites from within the same subestuary were sampled within a few days of one another.

Shoreline-type definitions follow Davias et al. (2014). Wetlands were stands of predominantly native emergent 
Fig. 1 Sample sites. Fishes were sampled in 16 subestuaries of the Chesapeake Bay at wetland, beach, bulkhead, and riprap shoreline types ( $n=188$ unique sites) from 2008 to 2012

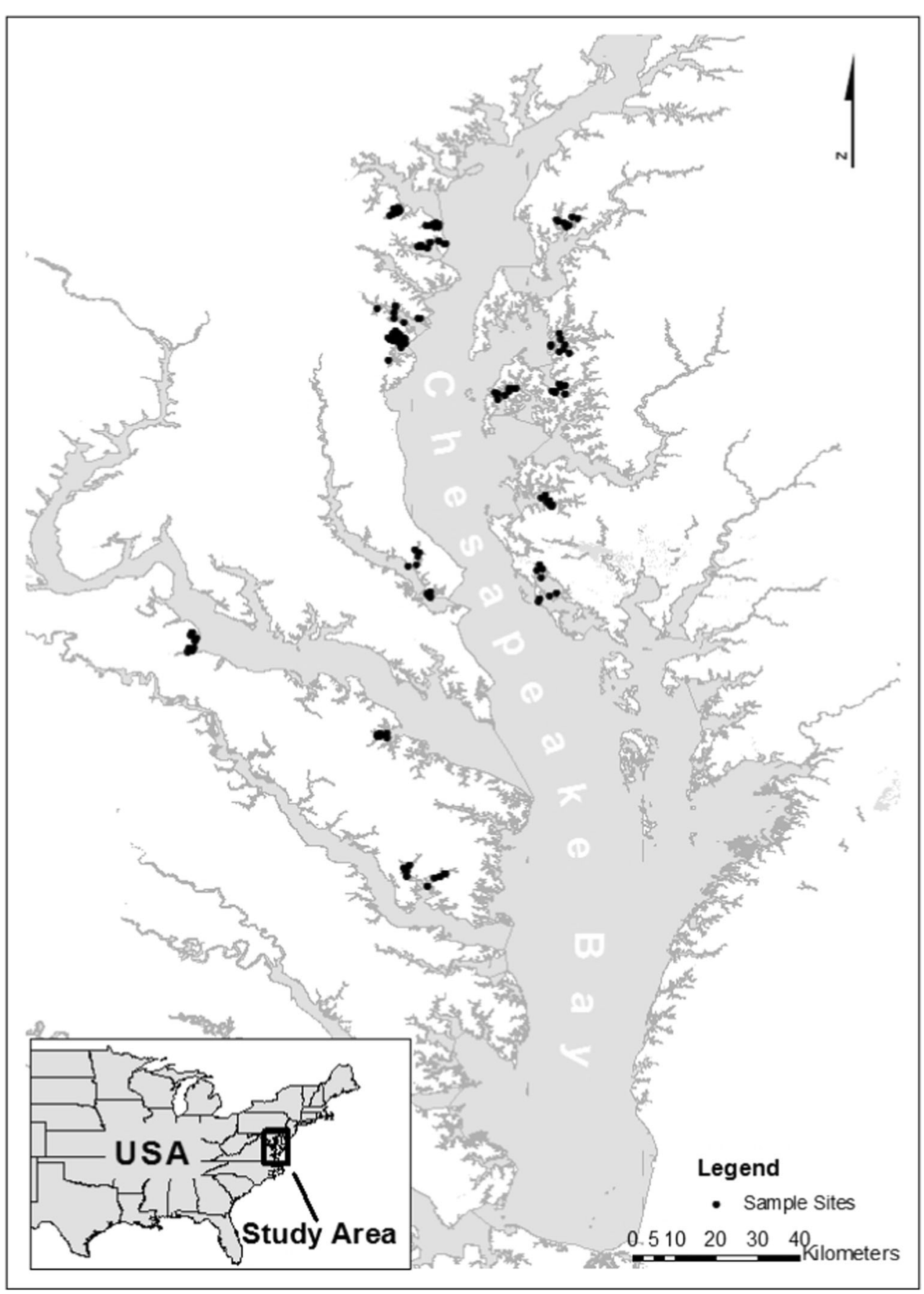

vegetation dense enough to form a platform that is inundated at high tide. Beaches were fine or coarse sandy substrate with an absence of large woody debris, fine organic material, or dense vegetation. Bulkheads were vertical retaining walls made of wood, vinyl, metal, or concrete. Ripraps (short for "riprap revetments") were shorelines armored primarily with large rock ( $>0.25 \mathrm{~m}$ diameter). Both bulkheads and ripraps had inundated vertical habitat at low tide, and bulkheads or ripraps that fronted wetland shorelines were excluded from sampling. Each site was located along a stretch of continuous shoreline represented by a single shoreline type extending at least $77 \mathrm{~m}$; no mixed shorelines were sampled. When possible, clusters of four sites (one of each shoreline type) were colocated within the same arm of a subestuary so that dispersal among sites within a cluster was possible for most species.

\section{Fish Processing}

Fish sampling occurred on the ebb tide within waters that extended $3 \mathrm{~m}$ (constant) and $16 \mathrm{~m}$ (on average) from shore 
at each shoreline type. Both zones were sampled simultaneously at each of 72 sites ( 18 of each shoreline type). Areas $3 \mathrm{~m}$ from shore were sampled at an additional 72 sites ( 18 per shoreline type) and areas $16 \mathrm{~m}$ from shore at an additional 44 sites (11 of each shoreline type). Areas $3 \mathrm{~m}$ from shore were sampled using a "nested parallel" method (Kornis et al. 2017). Fifteen minutes prior to pulling nested parallel seines, three PVC poles were placed $3 \mathrm{~m}$ from shore to mark the sampling area. To limit disturbing the shoreline community prior to sampling, seines were floated to each site from a boat located offshore. Two $15.2 \mathrm{~m}$ center-bagged beach seines were set in place in tandem parallel to shore at $3 \mathrm{~m}$ distance. Once taut, the ends of both nets were pulled into shore simultaneously. The outer net was positioned to create a barrier, and the inner net was then pulled. The second net was pulled immediately after captured individuals were removed from the first net and placed in a bucket with ambient water for processing. Areas within $16 \mathrm{~m}$ of shore $(16.1 \pm 3.1 \mathrm{~m}$ (s.d.) on average, based on maximum distance of seine net bag from shore) were sampled by deploying a $61-\mathrm{m}$ center-bagged beach seine by a specially designed shallow-draft skiff, with the engine mounted just aft of the bow, to maximize deployment speed (hereafter "boatdeployed" method). One person pulled one end of the big seine to shore and anchored it while the boat drove in an arc towards the second endpoint, rapidly enclosing the area to be sampled in $<60 \mathrm{~s}$ (Supplemental Video File, video credit to H. Soulen). At sites that were simultaneously sampled at waters extending both 3 and $16 \mathrm{~m}$ from shore, the boat-deployed seine was set first to enclose the area. Then, after waiting $15 \mathrm{~min}$ to allow the site to recover from disturbance, the nested parallel seines were set and pulled as described above prior to pulling the boat-deployed seine. All seines were constructed from Delta knotless material, 4.76-mm bar mesh. For both nested parallel and boat-deployed methods, a PVC pole was used to startle fish and crustaceans hiding along the shoreline towards the net bag as the net ends were drawn together. Captured individuals were identified, and a representative random sample of up to 50 individuals per species per seine net were measured for total length to the nearest millimeter (all individuals of a species were measured if $<50$ were present in the net). White perch and striped bass, two species with relatively broad length ranges that often occurred at $>50$ per sample, were divided into two length categories $(<150 \mathrm{~mm}$, $\geq 150 \mathrm{~mm}$ ) with up to 50 length measurements per category; catch in excess of 50 was also counted separately for each length category for these species. This was done to improve the biomass estimates by ensuring that representative measurements were taken at random from both large and small individuals of these species. Length categories were not needed for other species with broad length ranges (e.g., red drum, American eel) because these species were always encountered at $\leq 50$ per sample and thus all individuals were measured for length.

\section{Habitat Characteristics}

Prior to sampling fauna, water temperature, salinity, and dissolved oxygen were measured from a boat at each site using a YSI 600 QS (2010-2012, $n=144$ sites, 36 sites at each shoreline type). Sediment cores were collected for grain size analysis, and Secchi depth and volume of vegetative debris were also measured in 2011 and 2012. Six sediment cores $(31.75 \mathrm{~mm}$ diameter PVC cut to approximately $178 \mathrm{~mm}$ length) were collected at each site $(n=96$ sites, 24 of each shoreline type). Cores were collected at $3 \mathrm{~m}, 1.5 \mathrm{~m}$, and as close to shore as possible on either side (laterally) of the area to be seined. All six cores were pooled into the same bag and placed immediately on ice and remained frozen until grain size analysis could be completed in the laboratory. Percent of sediment comprised of gravel (particles $>2.0 \mathrm{~mm}$ ), sand (particles $0.25-2.0 \mathrm{~mm}$ ), and mud (particles $0.063-0.25 \mathrm{~mm}$ ) was assessed at each site (see Online Resource A for details). Secchi depth ( $0.1 \mathrm{~m}$ increments) was measured along the shaded side of the boat prior to faunal sampling by the same individual at all sites $(n=94,24$ beaches and ripraps and 23 bulkheads and wetlands (failure to record Secchi depth at 1 bulkhead and 1 wetland site was an oversight)). Vegetative debris was assessed from the nested parallel beach seines only and included the following categories: coarse woody debris, coarse leafy debris, filamentous algae, sea grass, Ulva spp., and terrestrial debris $(n=96$ sites, 24 of each shoreline type). The total volume of vegetative debris collected by both $15.2 \mathrm{~m}$ seines was roughly estimated by placing the debris into graduated cylinders for small quantities, or a 5 -gal bucket marked in $0.1 \mathrm{~L}$ increments for large quantities of debris. Habitat characteristics were not measured in 2008 (44 sites from the Rhode River).

Redundancy analysis (RDA) and single-factor blocked ANOVAs were used to analyze relationships between shoreline type and habitat characteristics. Redundancy analysis (Borcard et al. 1992) is a direct gradient technique that partitions variation in dependent variables (i.e., habitat characteristics) into components associated with the predictors (i.e., shoreline type). Although RDA is more commonly used to understand patterns in community composition (e.g., Angermeier and Winston 1999; Sharma et al. 2011), it is useful in our application of helping to visualize how habitat characteristics vary with shoreline type and co-vary with one another. Habitat characteristic data were z-standardized for the RDA such that all data were on the same unitless scale. Average values for a given habitat characteristic across all measurements were substituted in for missing data (e.g., Secchi depth, vegetative debris, and sediment grain size for sites sampled in 2008 and 2010) such that the missing values had no effect on the RDA outcome. Redundancy analysis does 
not test for statistical significance, and thus single-factor ANOVAs, blocked by subestuary of capture, were used to provide significance testing to determine whether each habitat characteristic differed among shoreline types.

\section{Biomass Estimation}

Total lengths were measured on 10,865 individuals within $3 \mathrm{~m}$ of shore and on 25,215 individuals within $16 \mathrm{~m}$ of shore, spanning a total of 49 taxa including 47 species and 2 genera. Pumpkinseed (Lepomis gibbosus) and bluegill (L. macrochirus), as well as Atlantic silverside (Menidia menidia) and inland silverside (M. beryllina), were grouped to genus due to difficulty distinguishing juveniles of these species while processing large numbers of individuals rapidly in the field. These 49 taxa were organized into functional groups based on habitat preferences and foraging behaviors (Table 1), which enabled examination of overall patterns across similar species. Unmeasured individuals in seines with $>50$ individuals per species were assumed to be the average length of measured individuals from that site (see equation below). Due to time constraints, grass shrimp carapace lengths were only measured on a subset of individuals ( $n=533$, collected on three dates during summer 2012 from one site and ranging from 9 to $58 \mathrm{~mm}$ total length), and the average length $(21.2 \pm 0.4 \mathrm{~mm})$ was used for all unmeasured grass shrimp (equivalent to $0.082 \mathrm{~g}$ per individual based on length-weight relationship in Hartman and Brandt 1995). Weight (g) was estimated for each individual using established length-weight relationships (carapace width instead of length for blue crab, wingspan instead of length for Atlantic stingray) (Online Resource B). Length-weight relationships could not be found for 10 species, and substitutions were made based on taxonomy or body shape as noted in Online Resource
B (Table B1). Biomass density $\left(\mathrm{g} \mathrm{m}^{-2}\right)$ for each species at each site was estimated by:

$B=\frac{W_{\text {ave }} \times N}{A}$

where $W_{\text {ave }}$ is the average estimated weight (g) of measured individuals captured at that site, $N$ is the total number of individuals caught (both measured and unmeasured), and $A$ is the area sampled $\left(\mathrm{m}^{2}\right)$. The catchability of seine nets (i.e., the $\%$ of present individuals captured by sampling gear) differed among species, net deployment methods, and among the four shoreline types. We therefore corrected the total number of individuals caught ( $N$ in above equation) based on catchability estimates ( $Q$ values) from four-net Leslie depletions conducted at 36 sites (nine sites each of beach, bulkhead, riprap, and wetland; Kornis et al. 2017). The percentage of present individuals likely to be captured by one seine pull $\left(Q_{1}\right)$ and by two seine pulls $\left(Q_{2}\right)$ were used to correct boat-deployed and nested parallel seine methods, respectively (see Kornis et al. 2017 for details). This corrected for sampling bias in capture efficiency specific to each shoreline type. The nested parallel method (samples within $3 \mathrm{~m}$ from shore) was probably not as efficient at sampling large-bodied fish as the boat-deployed method (16 $\mathrm{m}$ from shore) due to greater possibility of escape along the net edges. However, this difference between nested parallel and boat-deployed methods will not affect our comparisons among shoreline types, which were performed separately for each gear type.

\section{Utilization of Shoreline Types by Size Class}

We used two-sided bootstrapped Kolmogorov-Smirnov (KS) tests $(n=1000$ Monte Carlo simulations for each test) to
Table 1 Functional groups of studied taxa $(n=49)$, based on known habitat preferences and foraging behaviors (Murdy et al. 1997 for all finfish). The "other" functional group included unique species that generally had very small contributions to overall biomass. Species from the "other" group were included in biomass estimates for "all species". Scientific names are included in Online Resource B

\begin{tabular}{|c|c|c|}
\hline Functional group & Description & Included species \\
\hline Littoral-demersal & $\begin{array}{l}\text { Small-bodied bottom-oriented species that are frequently } \\
\text { found in extremely shallow water }(<20 \mathrm{~cm}) \text { and forage } \\
\text { on small littoral prey. Commonly serve as prey for larger species. }\end{array}$ & $\begin{array}{l}\text { Banded killifish, grass shrimp, green goby, mummichog, } \\
\text { naked goby, rainwater killifish, striped blenny striped } \\
\text { killifish, skilletfish, sheepshead minnow }\end{array}$ \\
\hline Planktivore & $\begin{array}{l}\text { Species that forage on phytoplankton and zooplankton and } \\
\text { tend to prefer open water. }\end{array}$ & $\begin{array}{l}\text { Alewife, Atlantic menhaden, Menidia spp., bay anchovy, } \\
\text { gizzard shad, spottail shiner, striped anchovy }\end{array}$ \\
\hline Benthivore/piscivore & $\begin{array}{l}\text { Large-bodied bottom-oriented species that forage on a suite } \\
\text { of benthic invertebrates and small fishes. }\end{array}$ & $\begin{array}{l}\text { American eel, Atlantic croaker, Atlantic ray, black drum, } \\
\text { blue crab, bluefish, brown bullhead, channel catfish, } \\
\text { chain pickerel, common carp, hogchoker, inshore } \\
\text { lizardfish, largemouth bass, Lepomis spp., red drum, } \\
\text { silver perch, spot, spotted seatrout, striped bass, } \\
\text { summer flounder, weakfish, white perch, yellow perch }\end{array}$ \\
\hline Other & $\begin{array}{l}\text { Unique species that do not readily fall into one of the other } \\
\text { three groups. }\end{array}$ & $\begin{array}{l}\text { Atlantic needlefish, harvestfish, lined seahorse, northern } \\
\text { pipefish, northern puffer, northern searobin, striped } \\
\text { burrfish, striped mullet }\end{array}$ \\
\hline
\end{tabular}


determine whether there were significant differences in the cumulative length distributions of fishes captured along the four shoreline types (Abadie 2002; Sekhon 2011). KS tests were conducted as pairwise comparisons between each unique pair of shoreline types; all species were included in the tests and separate tests were run within each distance from shore. Only individuals with field-measured lengths were used in this analysis ( $n=10,865$ within $3 \mathrm{~m}$ from shore and 25,215 within $16 \mathrm{~m}$ from shore). Unlike traditional $\mathrm{KS}$ analysis, the bootstrapped KS test can accommodate non-continuous distributions and point masses (i.e., data with ties; Abadie 2002; Sekhon 2011). This was important in our analysis because each length value (to the nearest $1 \mathrm{~mm}$ ) was associated with many individual fish.

To illustrate how size classes of fish utilized different shorelines, we grouped all sampled individuals into length bins using total length and examined the total percent of catch within each bin that occurred at the each of the four shoreline types. This was done for all species in aggregate and for each of the three specified functional groups (i.e., littoral-demersal, planktivore, and benthivore-piscivore, Table 1). Most length bins were 10-mm groups, but due to a skewed size distribution within $16 \mathrm{~m}$ of shore, we included two $50 \mathrm{~mm}$ length bins for larger individuals (301-350 and 351-400 mm). All bins had $\geq 20$ individuals for small nets and $\geq 50$ individuals for big nets.

\section{Taxonomic Distinctness}

We used taxonomic distinctness (TD) and the variation in taxonomic distinctness (VarTD) to evaluate whether biodiversity in estuarine fauna varied along shoreline types. Taxonomic distinctness, which measures taxonomic relatedness between species pairs in each sample as the mean path length through the taxonomic tree (Clark and Warwick 1998, 2001), has several advantages over traditional diversity measures (e.g., species richness) including insensitivity to sampling effort (as shown for Chesapeake Bay fish assemblages by Tuckey and Fabrizio 2013), ability to estimate phylogenetic diversity, and being more closely linked to functional diversity (Clarke and Warwick 1999; Leonard et al. 2006; Bilkovic and Mitchell 2013). Variation in taxonomic distinctness, which is not the variance of TD among samples but rather the variation in branch lengths among all pairs of species in each sample, assesses unevenness in the taxonomic hierarchy (Clarke and Warwick 2001). Moreover, the combination of average TD and VarTD can provide an indication of the relative degradation of assemblages from different locations (Clarke and Warwick 2001). Generally, the range of average TD values is narrow for a given assemblage (e.g., fishes) from a particular study area (e.g., Ellingsen et al. 2005), and thus seemingly small numeric differences may be meaningful. Two species (blue crab and grass shrimp, Phylum Arthropoda) may have had a large influence on TD and VarTD measures due to long path lengths with the other 39 observed species (fish, Phylum Chordata). Therefore, we estimated TD and VarTD both including and excluding the two arthropod species.

\section{Statistical Analyses}

Taxonomic distinctness and taxonomic variation were calculated using Primer version 6.1.15. analyses of variance (ANOVAs) were performed in $\mathrm{R}$ version 2.13.2, as were bootstrapped KS tests (function ks.boot, 'Matching' package). All ANOVAs included subestuary of capture as a blocking factor to account for possible confounding factors associated with subestuary, including date of capture, salinity, and subestuary-level differences in prey abundance, pollution, or habitat. For all statistical analyses, $\alpha=0.05$ was used as the threshold for statistical significance. However, we also report all $p$ values between 0.05 and 0.10 because they may indicate biologically relevant trends. Mean values are reported \pm standard error, except when noted by [s.d.] (standard deviation). Standard error was reported to assess confidence in the estimate of the mean, while standard deviation was reported to describe the magnitude of variation around the mean.

\section{Results}

\section{Habitat Characteristics}

Hardened shoreline types (i.e., bulkhead and riprap) had very similar environmental profiles, while beach and wetland habitats were more unique (Fig. 2). Water depth, Secchi depth, vegetative debris, and salinity differed significantly among shoreline types (Table 2). Water depth at 0 and $3 \mathrm{~m}$ from shore were positively correlated with bulkhead and riprap, while vegetative debris and Secchi depth were positively and negatively correlated, respectively, with wetlands (Fig. 2). Dissolved oxygen, water temperature, and sediment characteristics (\% gravel, sand, and mud) were not significantly related to shoreline type (Table 2), although there were negative associations between percent mud and beach, and percent gravel and wetland shoreline types (Fig. 2). On average, water depth at shore was $0.51 \mathrm{~m}$ deeper along hardened shorelines $(0.59 \pm 0.03$ and $0.54 \pm 0.04 \mathrm{~m}$ at bulkheads and ripraps, respectively) than natural shorelines $(0.12 \pm 0.02$ and $0.0 \pm 0.0$ at wetlands and beaches, respectively). Wetlands were also significantly deeper than beaches at shore. Water depth $3 \mathrm{~m}$ from shore was $0.26 \mathrm{~m}$ greater on average at hardened vs. natural shorelines, but water depth $16 \mathrm{~m}$ from shore (average distance) did not differ among shoreline types (Table 2). Secchi depth along wetland shorelines was significantly lower relative to the other three shoreline types (average difference of $0.11 \mathrm{~m}, p<0.006$ for all pairwise comparisons, Table 2). Wetlands also had more vegetative debris than all other habitats (Table 2, difference of $1.9 \mathrm{~L}$ on average, $p=0.05,0.05$, 


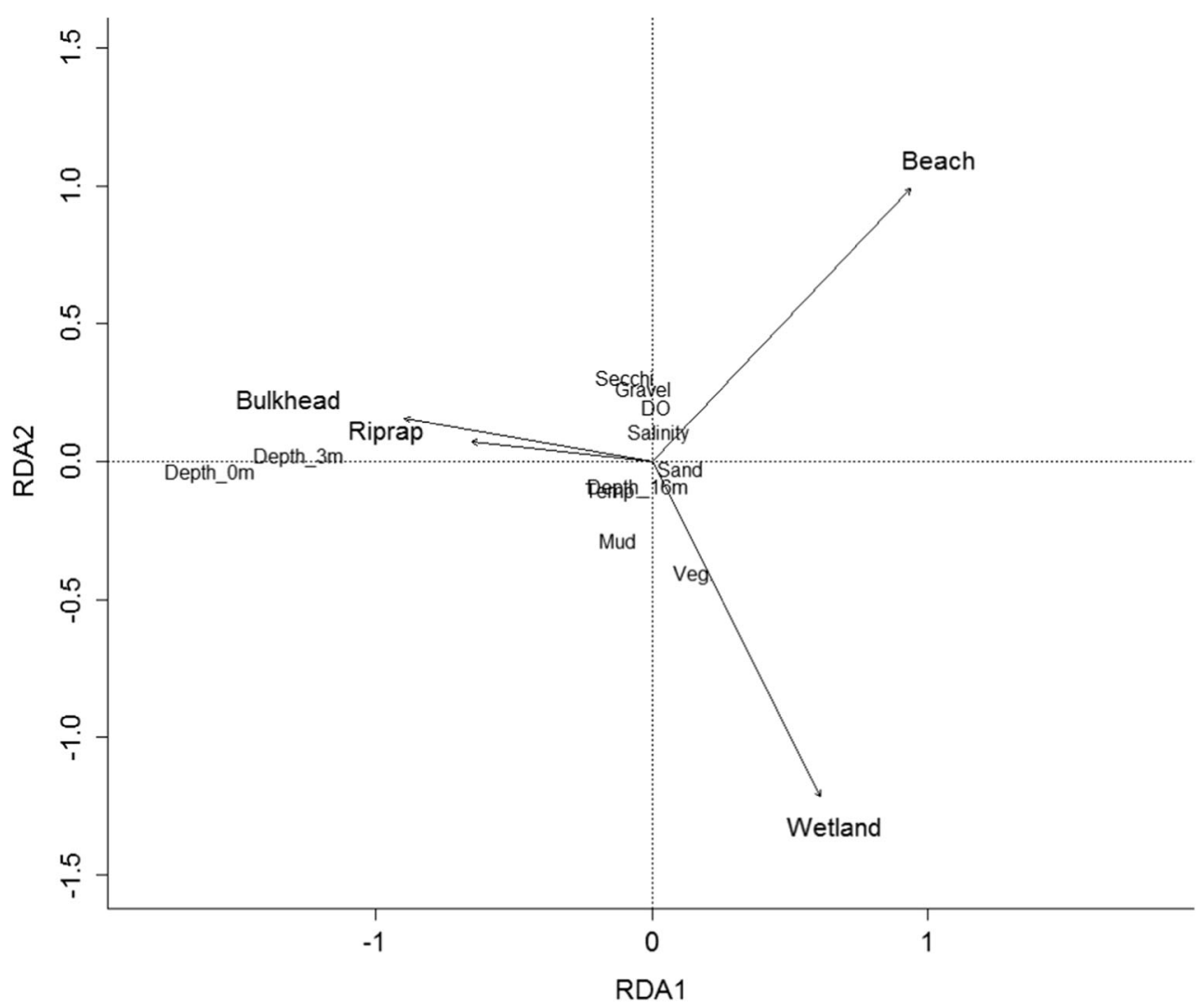

Fig. 2 Redundancy analysis (RDA) axes one and two showing associations between habitat characteristics with shoreline type. Habitat characteristics are shown in small black letters. Large, bold letters and arrows correspond with the four shoreline types. The direction of each arrow indicates how well each habitat characteristic correlates with shoreline type: habitat characteristics along the positive direction of each arrow (i.e., towards the point) are positively associated with that shoreline type, whereas habitat characteristics in the opposite direction

and 0.12 for comparisons with riprap, beach, and bulkhead, respectively). Average salinity was significantly higher at beach (11.2 \pm 0.4$)$ compared to wetland (10.8 \pm 0.04$)$ shorelines; however, this difference is not likely to be physiologically relevant to the fauna examined in this study.

\section{Biomass Density}

Effects of shoreline type on biomass density $\left(\mathrm{g} \mathrm{m}^{-2}\right)$ varied among functional species groups and between waters that extended 3 and $16 \mathrm{~m}$ from shore. Shoreline type had a significant effect on total biomass (i.e., all species in aggregate), benthivorepiscivore biomass, planktivore biomass, and littoral-demersal biomass within $3 \mathrm{~m}$ of shore (Table 3 , all $p \leq 0.001$ ). Total biomass density was largest along bulkheads compared to all other shoreline types (Fig. 3 top panel, $p<0.0001$ for pairwise comparisons with wetland and beach; $p=0.009$ for comparison with riprap). Total biomass density was also larger along riprap vs. beach shorelines $(p=0.06)$. This pattern was driven largely by benthivore-piscivore biomass, which accounted for of an arrow are negatively associated. Average water temperature is abbreviated as "Temp.;" average dissolved oxygen is abbreviated as "DO;" vegetative debris is abbreviated as "Veg.," and percent mud, gravel, and sand are abbreviated as "mud," "gravel," and "sand." Overlapping habitat characteristic codes at $(-0.1,-0.1)$ are Temp. and Depth_16m. Results of significance testing for the effect of shoreline type on each habitat characteristic are available in Table 2

77.7\% of all biomass captured within $3 \mathrm{~m}$ of shore and was largest along bulkhead compared to all other shoreline types $(p<0.0001$ for pairwise comparisons with wetland and beach; $p=0.003$ for comparison with riprap). Several taxa, including blue crab, Lepomis spp., spot, striped bass, and white perch contributed to larger benthivore-piscivore biomass at bulkheads. Planktivore biomass was also largest along altered shorelines (riprap > wetland $(p=0.01)$ and beach $(p=0.04)$; bulkhead $>$ wetland $(p=0.02)$ and beach $(p=0.07))$ within $3 \mathrm{~m}$ of shore, largely driven by a single taxa, Menidia spp. In contrast to other functional groups, littoral-demersal biomass was largest along wetlands compared to all other shoreline types (Fig. 3 top panel, $p=0.002,0.002$, and 0.10 in pairwise comparisons with beach, bulkhead, and riprap, respectively). Mummichog, grass shrimp, and striped killifish contributed the most to patterns in littoral-demersal species (Table 3).

Total biomass density was comparable among all four shoreline types in samples extending $16 \mathrm{~m}$, on average, from shore (Table $4 ; F_{3,77}=0.3, p=0.86$; Fig. 3 bottom panel); this was in contrast to patterns within $3 \mathrm{~m}$ of shore. The difference 
between the $16 \mathrm{~m}$ and extreme nearshore patterns was due to larger amounts of planktivore and benthivore-piscivore biomass at wetland and beach shorelines within $16 \mathrm{~m}$ of shore compared to within $3 \mathrm{~m}$ of shore (Fig. 2). Average planktivore biomass density increased from 1.1 to $37.4 \mathrm{~g} \mathrm{~m}^{-2}$ along beaches and from 0.7 to $26.0 \mathrm{~g} \mathrm{~m}^{-2}$ along wetlands ( $3 \mathrm{~m}$ vs. $16 \mathrm{~m}$ from shore for all comparisons). Similarly, average benthivore-piscivore biomass density increased from 0.3 to $15.9 \mathrm{~g} \mathrm{~m}^{-2}$ along beaches and from 5.0 to $21.2 \mathrm{~g} \mathrm{~m}^{-2}$ along wetlands. Nevertheless, benthivore-piscivore biomass density was still larger along hardened shoreline types (bulkhead $>$ wetland and beach $(p<0.0001$ for both); riprap $>$ wetland $(p=0.08)$ and beach $(p=0.02))$. Similarly, littoral-demersal biomass density remained largest along wetlands within $16 \mathrm{~m}$ of shore compared to all other shoreline types $(p<0.0001$ for all pairwise comparisons). Planktivore biomass density did not vary significantly among shorelines type within $16 \mathrm{~m}$ of shore (Table 4).

The average proportion of fish community biomass represented by different functional groups within $3 \mathrm{~m}$ of shore was very different between natural and hardened shoreline types (Fig. 4). Littoral-demersal species dominated along wetland and beach shorelines (58.4 and $54.3 \%$, respectively), while benthivore-piscivore species dominated along bulkhead and riprap shorelines (79.3 and $72.1 \%$, respectively). In contrast, benthivore-piscivores had the greatest fraction of fish community biomass at all four shoreline types within $16 \mathrm{~m}$ of shore (Fig. $4,50.3 \%$ at beaches, $53.3 \%$ at wetlands, $73.1 \%$ at ripraps, and $85.4 \%$ at bulkheads). Notably, planktivores contributed more to fish community biomass at beaches than at other shoreline types within both 3 and $16 \mathrm{~m}$ from shore.

\section{Utilization of Shoreline Types by Size Class}

Cumulative length distributions for all species pooled (Fig. 5) were unique for each of the four shoreline types, both within $3 \mathrm{~m}$ of shore (all $p<0.0001$; Fig. 5 upper panel) and within $16 \mathrm{~m}$ of shore (all $p<0.004$; Fig. 5 lower panel). However, cumulative length distributions were more similar within hardened and natural shoreline types than between them, based on the Kolmogorov-Smirnov test statistic, $D$, which is the maximum vertical deviation between two cumulative length distribution curves. Within $3 \mathrm{~m}$ from shore, bulkhead vs. riprap $(D=0.12)$ and wetland vs. beach $(D=0.17)$ were more similar than comparisons between hardened and natural shoreline types ( $D$ values ranged from 0.41 to 0.46 for the comparisons bulkhead vs. beach, bulkhead vs. wetland, riprap vs. beach, and riprap vs. wetland). Similarly, bulkhead vs. riprap $(D=0.05)$ and wetland vs. beach $(D=0.03)$ were more similar within $16 \mathrm{~m}$ of shore than comparisons between hardened and natural shoreline type ( $D$ values ranged from 0.20 and 0.21 for the comparisons bulkhead vs. beach, bulkhead vs. wetland, riprap vs. beach, and riprap vs. wetland). $D$ values were also greater for comparisons within $3 \mathrm{~m}$ of shore than within $16 \mathrm{~m}$ of shore, 


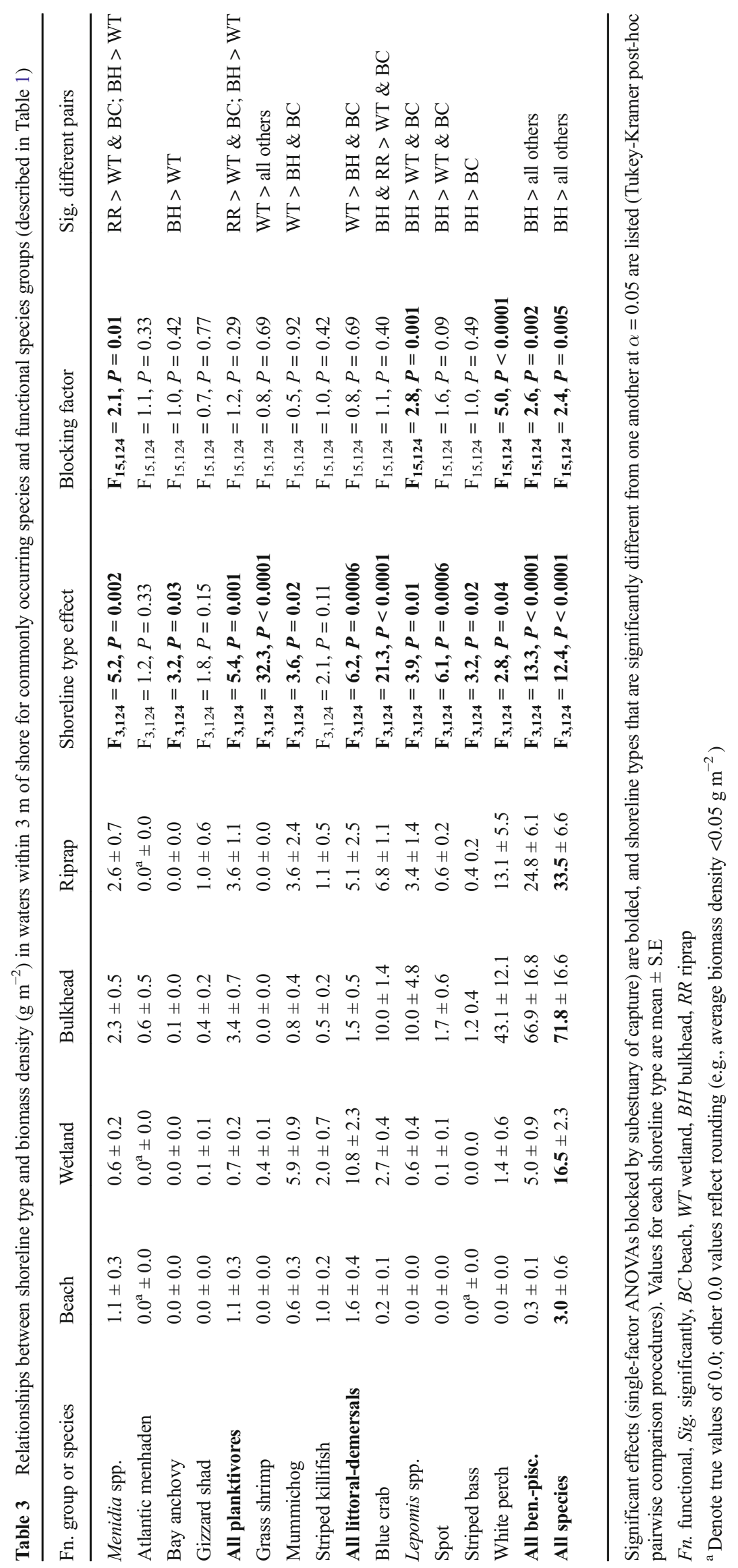


Fig. 3 Average biomass density ( $\mathrm{g} \mathrm{m}-2)$ of all species and three functional groups along natural (beach, wetland) and hardened (bulkhead, riprap) shoreline types. Error bars are \pm S.E. Biomasses were estimated from length data using established length-weight relationships (Online Resource B). Areas $3 \mathrm{~m}$ from shore were sampled by stretching two $15.2 \mathrm{~m}$ beach seines parallel to shore at $3 \mathrm{~m}$ distance, then pulling the endpoints of both nets into shore simultaneously. Areas $16 \mathrm{~m}$ from shore were sampled a 61-m seine deployed by boat; one person pulled one end of the big seine to shore and anchored it while the boat drove in an arc towards the second endpoint. At sites that were simultaneously sampled at both 3 and $16 \mathrm{~m}$ from shore, the 61-m seine was deployed first to enclose the area, and individuals captured within $3 \mathrm{~m}$ of shore were included in the data collected within $16 \mathrm{~m}$ from shore

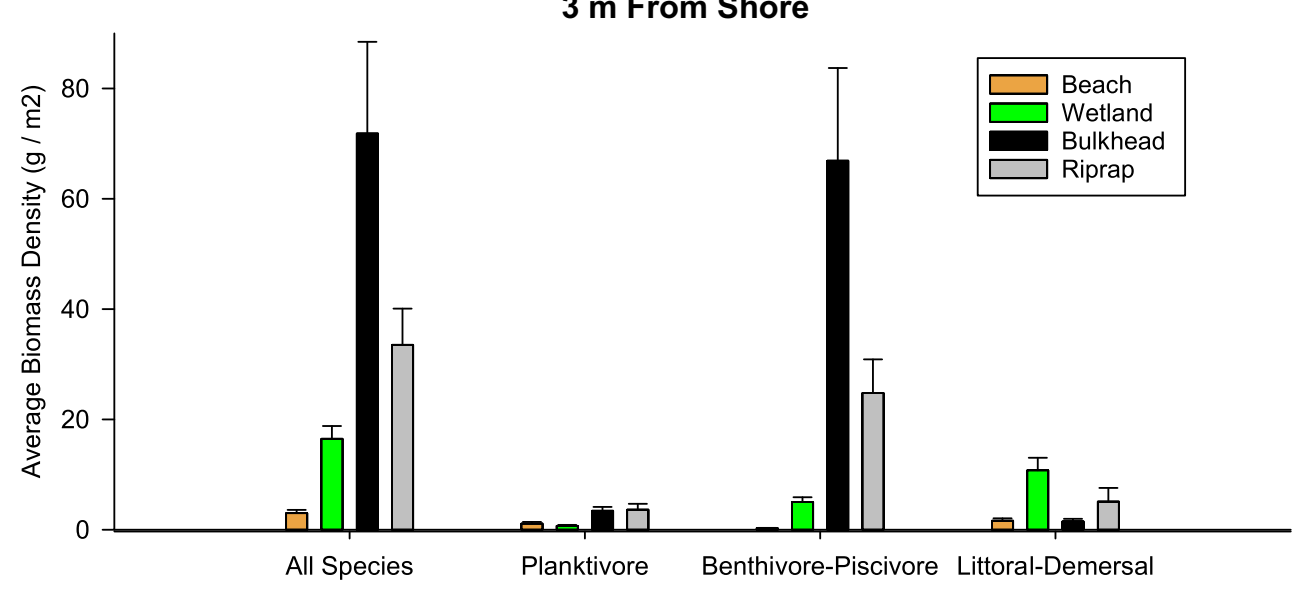

16 m From Shore

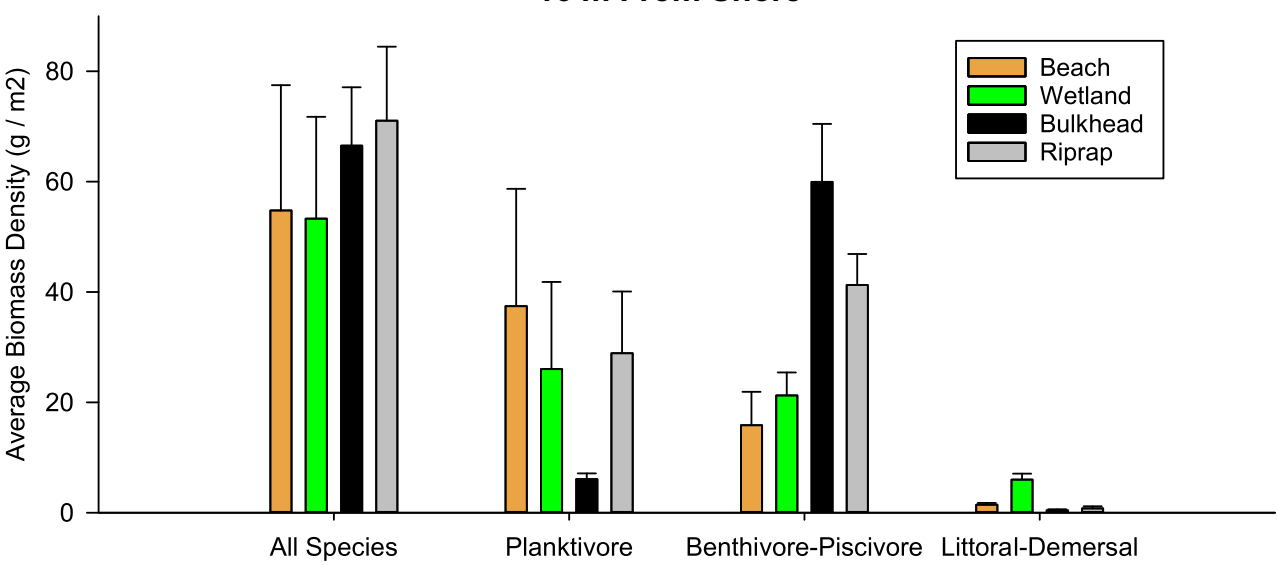

suggesting increased similarity in cumulative length distributions at the greater distance from shore.

Shoreline type utilization was clearly related to body size within $3 \mathrm{~m}$ of shore, with percent of catch at hardened shorelines increasing with body size (Fig. 6). Approximately $90 \%$ of all individuals $\leq 40 \mathrm{~mm}$ were captured at either wetland or beach shorelines, while approximately $90 \%$ of all individuals $\geq 115 \mathrm{~mm}$ were captured at either bulkhead or riprap shorelines. This pattern held true for all functional species groups. For example, even though the average biomass densities of benthivore-piscivores and planktivores were significantly greater at hardened shorelines within $3 \mathrm{~m}$ of shore (Fig. 3, Table 3), approximately $60 \%$ of benthivore-piscivores (Fig. 6 lower left panel) and planktivores (Fig. 6 upper right panel) $\leq 50 \mathrm{~mm}$ were captured along natural shorelines. Most small benthivore-piscivores were captured along wetlands, while most small planktivores were captured at beaches. Similarly, approximately $65 \%$ of littoral-demersal individuals $>100 \mathrm{~mm}$ were captured at hardened shorelines, especially riprap (Fig. 6 lower right panel), despite significantly greater biomass density of littoral-demersals at wetland habitats (Fig. 3, Table 3). In fact, the percent of littoral-demersals captured at riprap shorelines started to increase for individuals $>70 \mathrm{~mm}$.
Patterns between body size and shoreline type within $16 \mathrm{~m}$ of shore were similar to the patterns observed within $3 \mathrm{~m}$ of shore in that smaller individuals were most abundant at natural shorelines and larger individuals at hardened shorelines, but differences between shoreline types were much less distinct. Approximately $65 \%$ of all individuals $\leq 40 \mathrm{~mm}$ were captured at either wetland or beach shorelines, while approximately $50-70 \%$ of individuals $\geq 100 \mathrm{~mm}$ were captured along either bulkhead or riprap shorelines (Fig. 7 upper left panel); benthivore-piscivore species followed a similar pattern (Fig. 7 lower left panel). Planktivore patterns were highly variable, and two planktivore size classes (90-140 and 180$240 \mathrm{~mm}$ ) were strongly associated with natural shorelines. Post-hoc analyses suggested these size classes were predominantly Atlantic menhaden (approximately 75 and 65\% for the smaller and larger size ranges, respectively). Littoral-demersal species of all sizes were overwhelmingly captured along natural shorelines within $16 \mathrm{~m}$ of shore (Fig. 6 lower right panel).

\section{Taxonomic Distinctness-All Species}

Shoreline type had a significant effect on taxonomic distinctness (TD) both within $3 \mathrm{~m}$ of shore $\left(\mathrm{F}_{3,124}=5.5, p=0.001\right)$ 


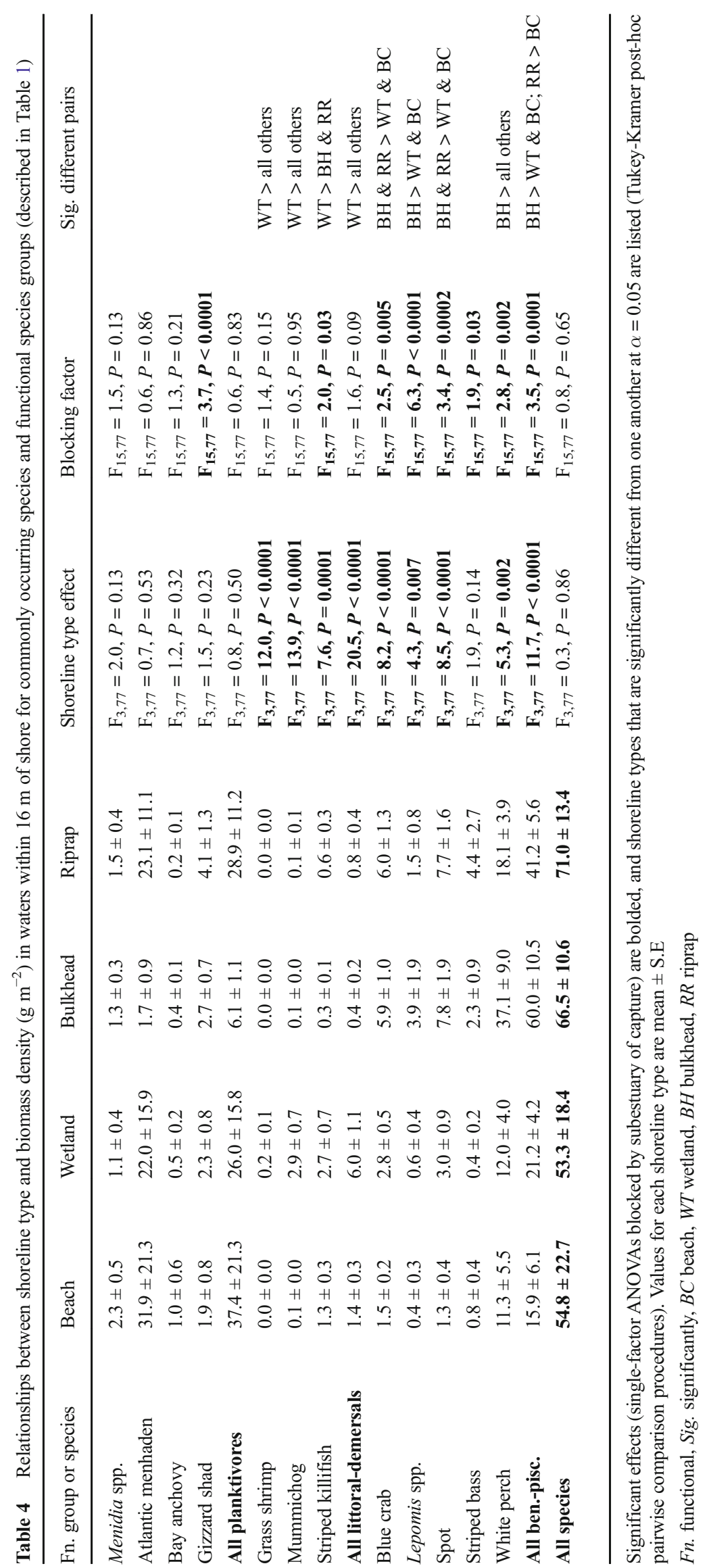


Fig. 4 The average percentage of total fish community biomass represented by different functional groups within $3 \mathrm{~m}$ of shore and $16 \mathrm{~m}$ of shore. Areas $3 \mathrm{~m}$ from shore were sampled by stretching two $15.2 \mathrm{~m}$ beach seines parallel to shore at $3 \mathrm{~m}$ distance, then pulling the endpoints of both nets into shore simultaneously. Areas $16 \mathrm{~m}$ from shore were sampled a 61-m seine deployed by boat

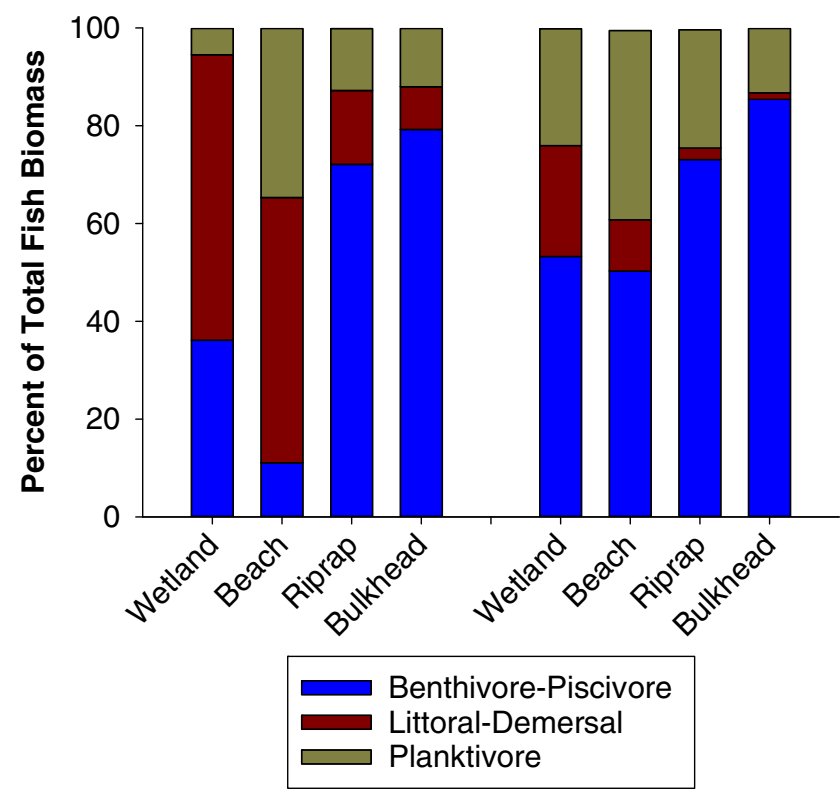

$p=0.056)$. Pairwise comparisons within $3 \mathrm{~m}$ of shore were similar, with less TD along beach shorelines $(51.1 \pm 3.7)$ than riprap $(58.7 \pm 1.8, p=0.09)$ wetland $(58.1 \pm 1.1, p=0.14)$ and bulkhead $(58.0 \pm 1.9, p=0.15)$ shorelines. Within $16 \mathrm{~m}$ of shore, finfish TD was generally comparable among shoreline types, but tended to be greater along beach $(62.2 \pm 0.3)$ and wetland $(61.8 \pm 0.2)$ shorelines than bulkhead $(61.1 \pm 0.4)$ or riprap $(61.3 \pm 0.3)$ shorelines; only the comparison between beach and bulkhead had a $p<0.1(p=0.06)$. VarTD at wetlands within $3 \mathrm{~m}$ from shore changed substantially with the exclusion of crustaceans. Nonetheless, VarTD of finfish tended to differ among shoreline types within $3 \mathrm{~m}$ of shore $\left(\mathrm{F}_{3,124}=2.3\right.$, $p=0.08)$ but not within $16 \mathrm{~m}$ of shore $\left(\mathrm{F}_{3,77}=0.46\right.$, $p=0.71)$. Finfish VarTD was higher along natural shorelines (wetland $=224.5 \pm 23.6$; beach $=211.8 \pm 34.4$ ) than hardened shorelines (bulkhead $=167.3 \pm 19.8$; riprap $=145.5 \pm 23.8$ ), but no pairwise comparison was significant (lowest $p$ was 0.11 for the comparison between wetland and riprap).

\section{Discussion}

Our results indicate that the response of estuarine fish and crustacean biomass and size structure to shoreline hardening varies substantially among functional groups, and also by the width of the land/water ecotone considered. The likelihood of species-group-specific responses to shoreline hardening has been hypothesized by others (e.g., Munsch et al. 2016; Gittman et al. 2016a) but has largely been overlooked in empirical analyses - in part because information on the ecological effects of shoreline hardening has been sparse until very recently (Dugan et al. 2011). As a result, earlier works on fish and crustaceans emphasized broad-brush effects on total 
Fig. 5 Cumulative length distributions along wetland, beach, riprap, and bulkhead shoreline types. All species and functional groups are included
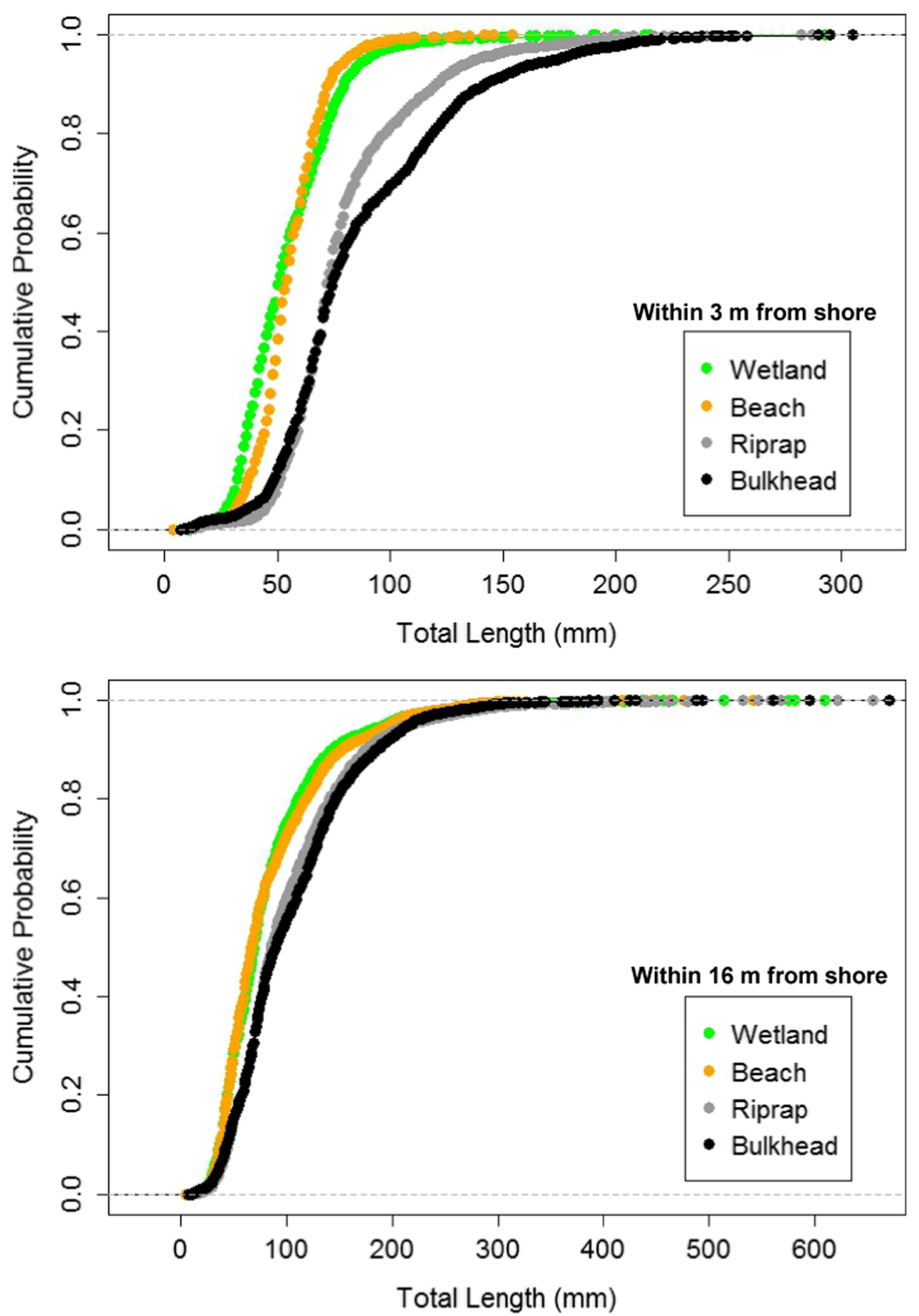

abundance and diversity (Gittman et al. 2016a) and effects on small-bodied and juvenile fish most likely to be affected by disruption to natural shorelines (e.g., Peterson et al. 2000; Rozas et al. 2007). These works contributed substantially to our understanding of how shoreline hardening affects estuarine fauna, but our study offers an improved understanding of the nuances of shoreline type effects, with important applications for management.
The biomass response of littoral-demersal species to shoreline hardening that we found was consistent with prior studies, but the high amounts of benthivore-piscivore and planktivore biomass at bulkheads relative to other shoreline types contrasted with general findings on total species abundance. A recent meta-analysis of 54 published studies found a substantial effect of bulkheads/seawalls on flora, benthic infauna, birds, epibiota, and nekton, noting $23 \%$ lower biodiversity and 

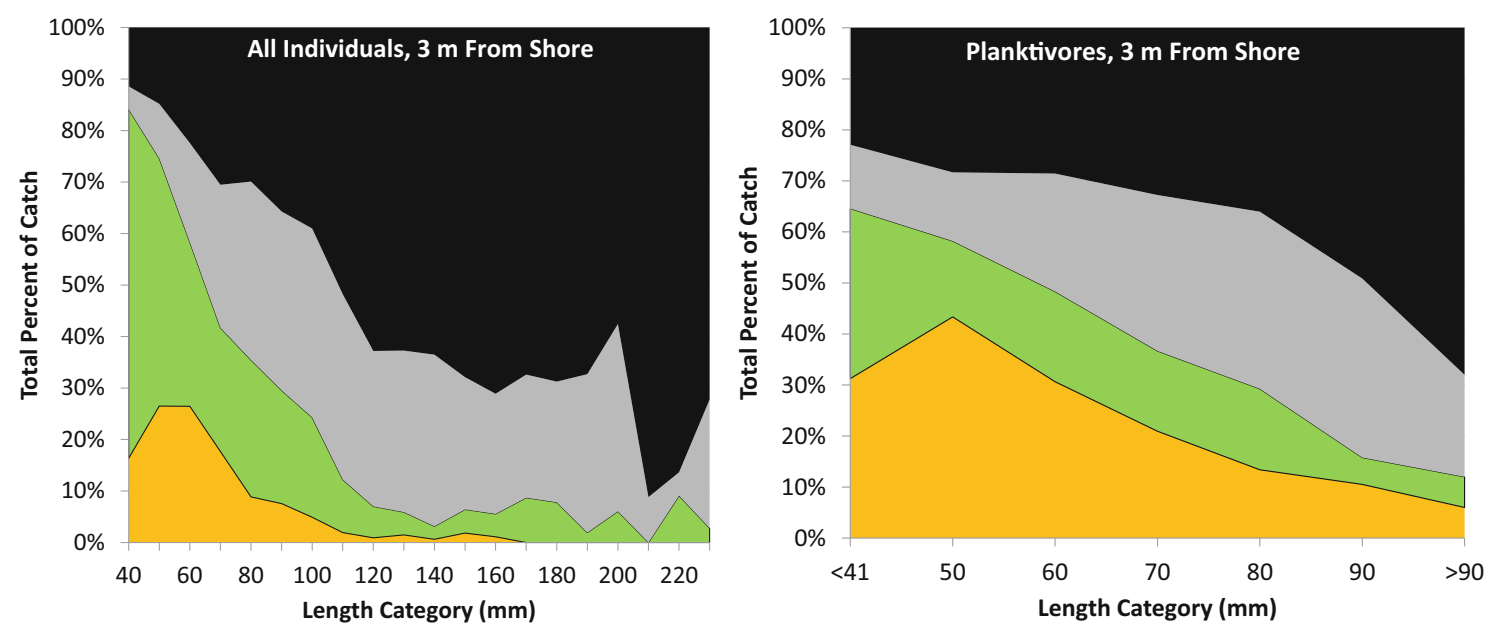

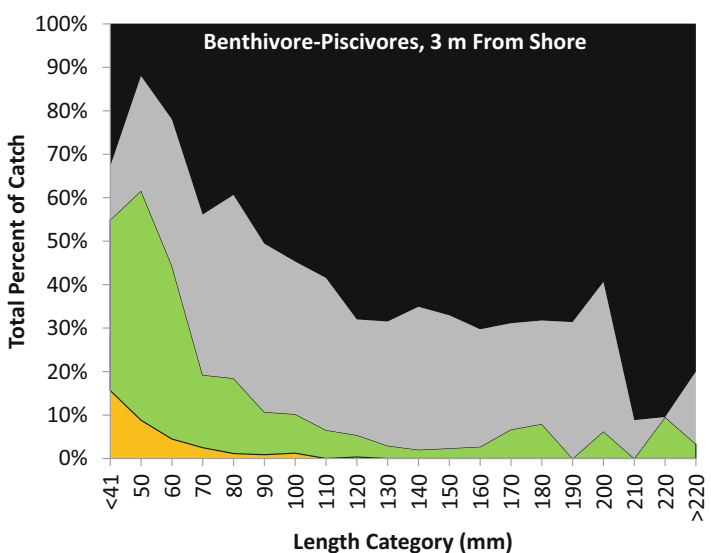

Beach

Fig. 6 Utilization of waters within $3 \mathrm{~m}$ of natural (wetland, beach) and hardened (bulkhead, riprap) shoreline types by fishes of different size classes, measured by percent of catch. The border line of the gray and green areas reflects the total percent of catch from natural shoreline types. All sampled individuals are grouped into $10 \mathrm{~mm}$ length bins, and each bin is represented along the $x$-axes by the upper limit (e.g., "60" refers to individuals that are 51-60 mm). The lowest size bin in all panels contains

$45 \%$ lower organism abundance relative to natural shorelines (Gittman et al. 2016a). Although these general patterns are important, both biomass (this study) and abundance (Munsch et al. 2015; Kornis et al. 2017) data indicate that the response to shoreline hardening varies substantially among species. Earlier studies have also documented this variability in the context of resident vs. transient species. Lowe and Peterson (2014), for example, found that small-bodied resident species are more negatively impacted by wetland fragmentation and loss to hardened structures than transient species that can easily move between locations (Lowe and Peterson 2014). This finding is consistent with our observations of strongly reduced biomass of small-bodied littoral-demersal species, which include several wetland residents (e.g.,

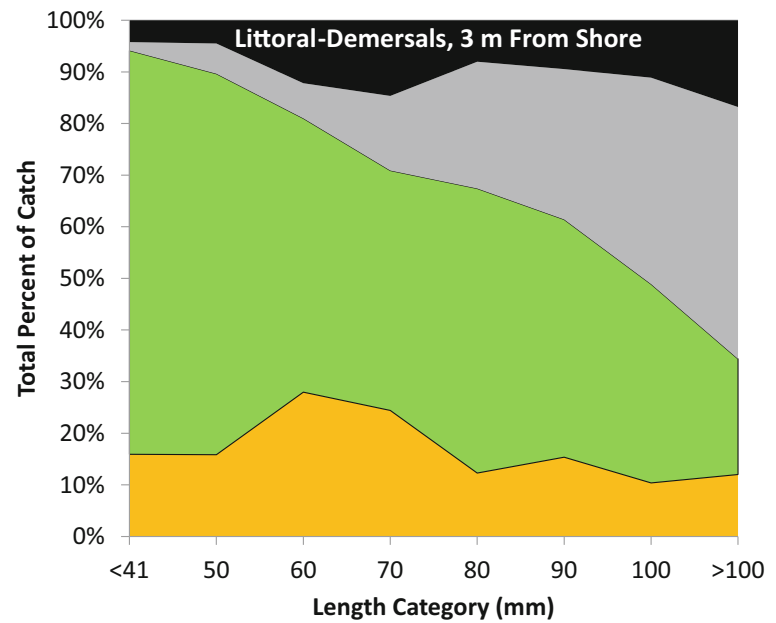

\section{Riprap Bulkhead}

individuals that are $0-40 \mathrm{~mm}$. The upper size bin varied by species group in order to maintain at least 20 individuals in each length bin, and thus the $x$-axes are not consistent among panels. The upper size bin in the panels for all individuals and for benthivore-piscivores contains individuals $>220 \mathrm{~mm}$, compared to $>90 \mathrm{~mm}$ for planktivores and $>100 \mathrm{~mm}$ for littoral-demersals. As a result, patterns for all individuals are driven predominantly by benthivore-piscivores at lengths $>100 \mathrm{~mm}$

mummichog, striped killifish, grass shrimp), but increased biomass of more transient species comprising the benthivore-piscivore group (e.g., spot, striped bass, blue crab) along bulkheads and riprap revetments.

Although functional-group-specific responses to shoreline type were important, patterns in size-class-specific utilization of shoreline type superseded functional group-specific biomass responses - particularly within the extreme nearshore zone within $3 \mathrm{~m}$ of the shoreline. Cumulative length distributions were significantly different among all shoreline types. However, the magnitude of difference was much greater between hardened and natural shoreline types than between shoreline types within the hardened (i.e., bulkhead vs. riprap) or natural (i.e., wetland vs. beach) shoreline groups. Large 

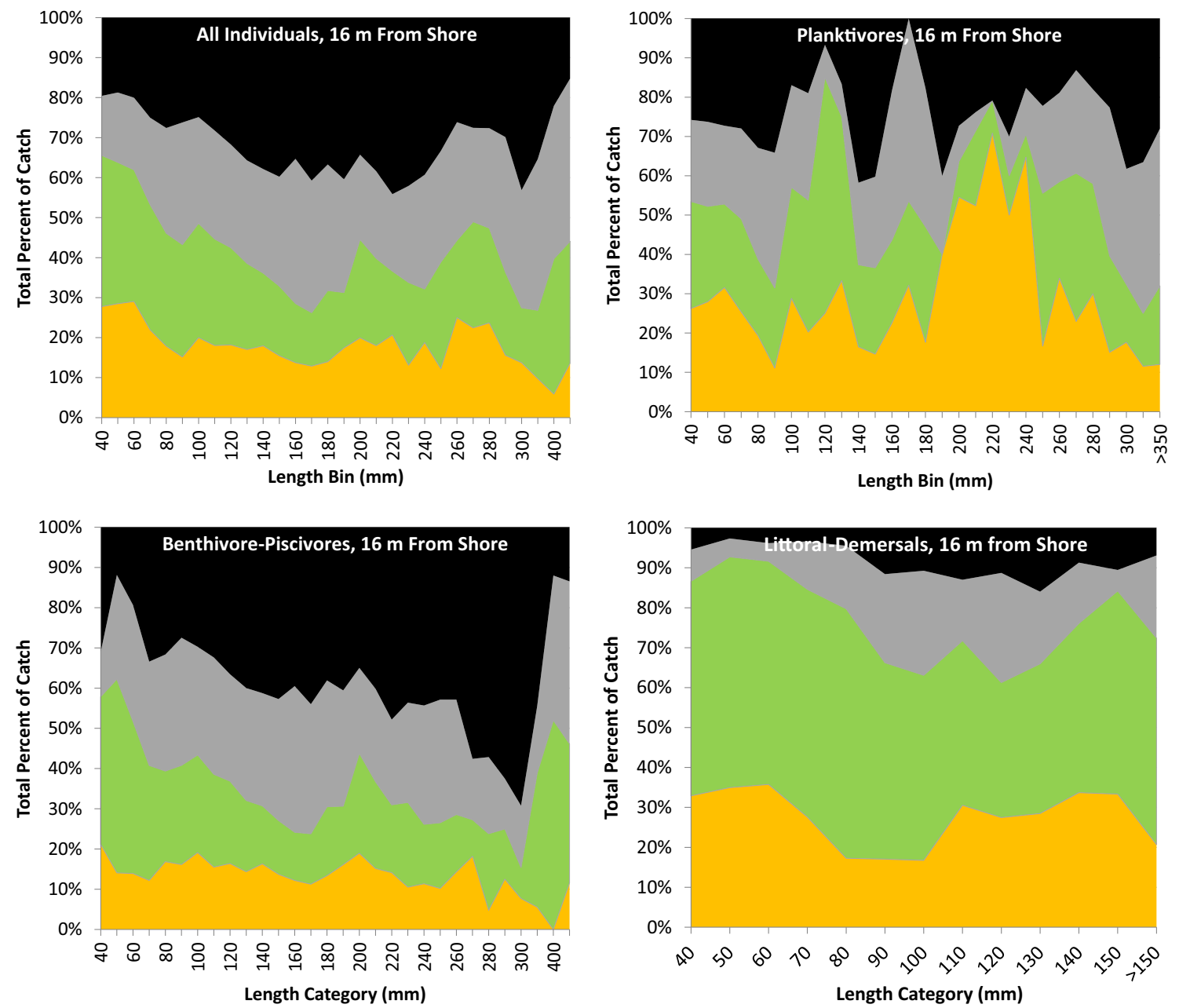

\section{Beach $\square$ Wetland}

Fig. 7 Utilization of waters within $16 \mathrm{~m}$ of shore (on average) of natural (wetland, beach) and hardened (bulkhead, riprap) shoreline types by fishes of different size classes, measured by percent of catch. The border line of the gray and green areas reflects the total percent of catch from natural shoreline types. Sampled individuals are grouped into $10 \mathrm{~mm}$ length bins, except for two $50 \mathrm{~mm}$ length bins (301-350 and $351-400 \mathrm{~mm}$ ) for larger sizes. Each bin is represented along the $x$ axes by the upper limit (e.g., "60" refers to individuals that are 51$60 \mathrm{~mm}$ ). The lowest size bin in all panels contains individuals that are

sample sizes may also have contributed to statistically significant differences among similar cumulative length distributions for wetland vs. beach and bulkhead vs. riprap. Differences between hardened vs. natural shoreline types, rather than within each type, are therefore likely to have the greatest biological importance and are the focus of our discussion.

Small individuals of every functional group were more abundant along natural shoreline types, supporting findings of a plethora of studies documenting the importance of natural shorelines, especially wetlands, as nursery habitats (e.g., Beck et al. 2001; Minello et al. 2003; Rozas et al. 2007; Sheaves et al. 2015). Even benthivore-piscivores, whose biomass was largely associated with bulkhead and riprap shorelines, were most often found along natural shorelines at small sizes, consistent with earlier studies (e.g., Hodson et al. 1981; Ross 2003; Nemerson and Able 2003, 2004; Able et al. 2012) including one showing that fish transitioned from extreme shallows to deeper waters as they grew (Munsch et al. 2016). Similarly, larger-bodied individuals of all functional groups were more likely to be encountered at hardened shoreline types. Although this pattern was driven by benthivorepiscivores and planktivores for individuals $>150 \mathrm{~mm}$ in size, even littoral-demersal species show this pattern for larger individuals within that species group $(90-150 \mathrm{~mm}$ ) that 

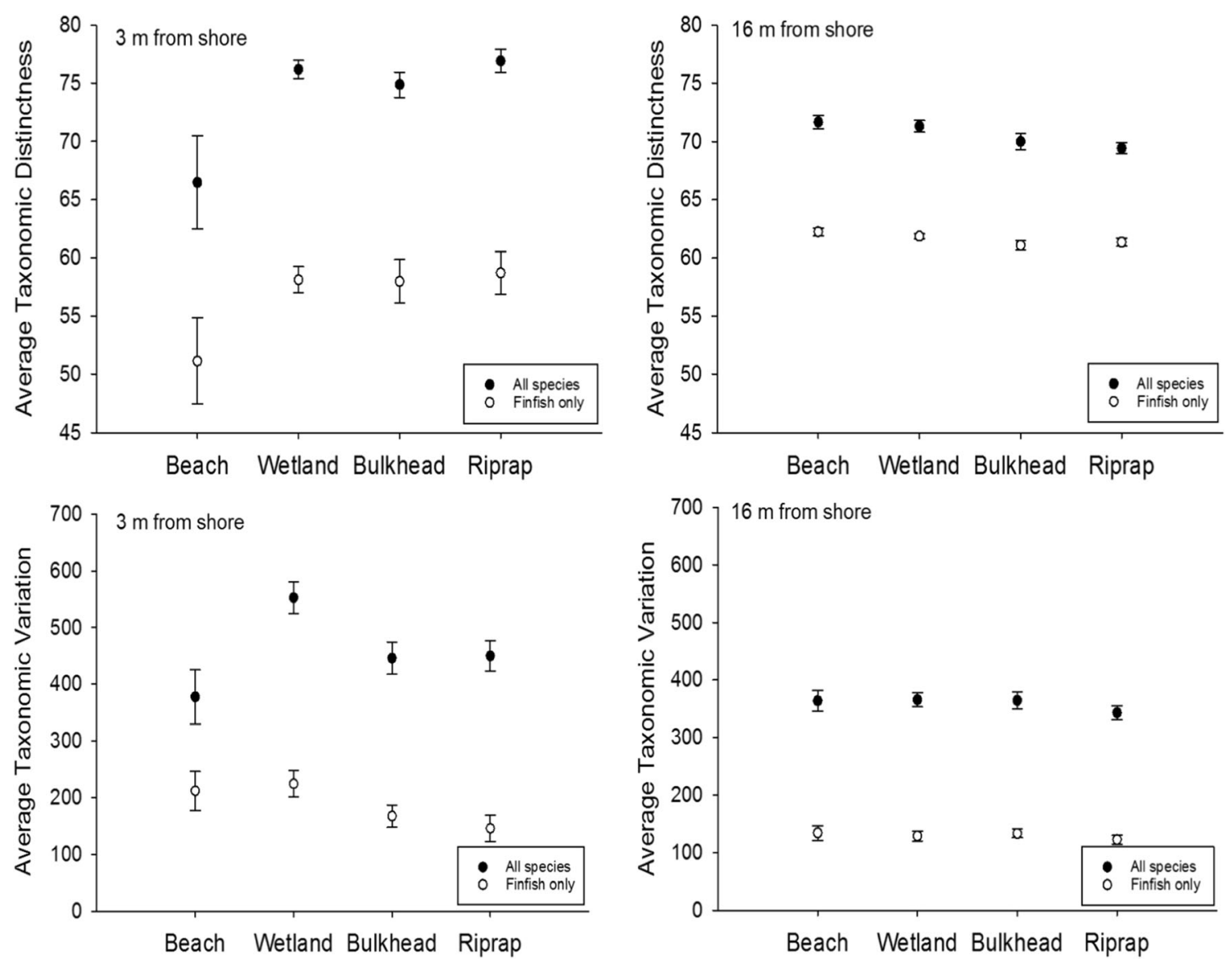

Fig. 8 Average taxonomic distinctness (upper panels) and taxonomic variation (lower panels) along four commonly occurring shoreline types. Closed black cricles include all taxa (both finfish and crustaceans), while open white circles include only finfish species. Error bars are \pm S.E.

predominantly associated with riprap habitat. These findings suggest the heavy utilization of hardened shorelines by some functional groups may be at least partially dependent upon the existence of nursery and refuge habitat provided by natural shorelines, a hypothesis consistent with many earlier works showing the integration of nursery production to broader systems (e.g., Childers et al. 2000; Weinstein et al. 2005; Sheaves et al. 2015). Moreover, a study from Puget Sound noted similar effects of shoreline hardening on fish size distributions (Munsch et al. 2016), suggesting shoreline hardening effects on fish size distribution-including predation risk as perceived by fish (see below) — may be generalizable among systems.

The fact that size-class-specific shoreline utilization patterns were much stronger within $3 \mathrm{~m}$ of shore compared to $16 \mathrm{~m}$ of shore suggests a mechanism of shoreline hardening largely specific to waters immediately at the land/water interface. We argue that this mechanism is most likely increased water depth and the elimination of shallow-water habitat at hardened shorelines. Average depth at shore for both bulkhead and riprap habitats was over $0.5 \mathrm{~m}$, and vertical bulkhead and riprap habitats were inundated even at low tide. The exclusion of shallow-water habitat, including horizontal intertidal areas in marine systems, substantially reduces the value of nearshore habitat as refuge from predators. Prior studies have noted the importance of shallow-water habitat for predation refuge, and by extension, the increased predation risk associated with deeper waters (Ruiz et al. 1993; Hines and Ruiz 1995; Patterson and Whitfield 2000). Water depth/intertidal habitat also likely explained the strong association of littoraldemersal biomass with natural shorelines. Small resident fishes have repeatedly been shown to prefer shallow water, and large predatory species to prefer deep water (Akin et al. 2003; $\mathrm{Ng}$ et al. 2007), although Becker and Suthers (2014) found predatory species tend to increase their presence in shallow habitats $(\approx 1 \mathrm{~m}$ deep$)$ at night.

Size-class utilization patterns may also be driven by environmental characteristics or food availability. We found that wetland shorelines had reduced water clarity and greater amounts of vegetative debris, both of which enhance the value of wetland habitats as refuge for small-bodied individuals, especially from visual predators. In addition, Bilkovic and Roggero (2008) found greater amounts of subtidal benthic structure (e.g., shellfish beds, woody debris) along wetland 
shorelines. Natural shorelines with shallow waters also have ample sources of food for small-bodied or juvenile fish (Seitz et al. 2006; Sobocinski et al. 2010). Both gut contents and stable isotope signatures, which can reflect feeding in wetland areas even at small spatial scales (Davias et al. 2014), suggest juvenile benthivore-piscivores from a variety of species including Scianeids and Moronids feed in wetland areas (Able et al. 2001; Nemerson and Able 2003, 2004; Weinstein et al. 2010). For example, spot undergo an ontogenetic diet shift from planktivores as postlarvae to benthic feeders as juveniles, and during this critical transition spot typically feed in shallow intertidal wetland habitats (Hodson et al. 1981), where both zooplankton (David et al. 2016) and benthic invertebrates (King et al. 2005; Seitz et al. 2006; Bilkovic et al. 2006) are plentiful.

Our observation of high biomass of benthivore-piscivores at bulkheads and riprap revetments has implications for the effect of fish on benthos, and vice versa, along hardened shorelines. High biomass of benthivore-piscivores could exert substantial predation pressure on benthic prey. Indeed, decreased or altered prey resources have been reported along hardened shorelines (King et al. 2005; Seitz et al. 2006; Bilkovic et al. 2006; Heerhartz et al. 2015); some species (e.g., juvenile Pacific salmon) have been shown to feed at high rates along both hardened and natural shoreline types (Heerhartz and Toft 2015); and slight negative relationships between predator abundance and benthic infaunal biomass and diversity have been shown in nearshore areas (within $4 \mathrm{~m}$ of shore) by at least one study (Lawless and Seitz 2014). Conversely, hardened shorelines could alter prey resources independent of predation pressure, as reported by Lawless and Seitz (2014) for benthic infaunal density. Small fish may also avoid deeper waters created by shoreline armoring (Munsch et al. 2016), given the value of shallow waters as refuge habitat (Ruiz et al. 1993; Hines and Ruiz 1995). Alterations to prey resources could in turn negatively affect fish condition along hardened shorelines. For example, empty stomachs and different prey items found in gulf killifish and spot from hardened wetlands in coastal Mississippi (i.e., wetlands that were fragmented and dominated by hardened surfaces) contributed to lower body condition of those species (Lowe and Peterson 2015). We do not have direct evidence of either mechanism in our study, but based on our biomass findings, we speculate that shoreline hardening will likely affect predator-prey dynamics in nearshore waters.

Differences in biomass responses at extreme nearshore interface areas and broader nearshore zones (defined in our study as waters extending 3 and $16 \mathrm{~m}$ from shore, respectively) suggest that biomass patterns may be driven by small-scale distributional shifts related to shoreline characteristics within $3 \mathrm{~m}$ from shore. For example, total biomass across all groups was substantially greater at bulkheads than all other types within $3 \mathrm{~m}$ from shore, but did not differ among shoreline types within
$16 \mathrm{~m}$ from shore. Similarly, overall size-specific shoreline utilization was more similar among shoreline types within $16 \mathrm{~m}$ from shore than within $3 \mathrm{~m}$ from shore, although littoraldemersal species were an exception. We speculate that this difference is driven by greater depth-at-shore at bulkheads, which facilitated access of large-bodied, biomass-rich individuals to waters within $3 \mathrm{~m}$ from shore. Similarly, the high biomass of planktivores at riprap and bulkhead shorelines relative to wetland and beach shorelines within $3 \mathrm{~m}$ of shore may reflect deeper water and similarity to open-water habitat. Within $16 \mathrm{~m}$ of shore, bulkheads held the lowest biomass of planktivores relative to other shoreline types ( $6.1 \mathrm{vs} . \geq 26.0 \mathrm{~g} \mathrm{~m}^{-2}$ ). Taken together, this suggests that planktivores at bulkheads were congregated within $3 \mathrm{~m}$ of shore. Predation risk in the 3 to $16 \mathrm{~m}$ zone may have been higher than in waters extending only $3 \mathrm{~m}$ from shore, as the benthivore-piscivore assemblage included larger individuals within $16 \mathrm{~m}$ from shore than within $3 \mathrm{~m}$ from shore. In addition, planktivorous fish biomass may have been higher along wetland and beach shoreline types within $16 \mathrm{~m}$ from shore than in the narrower $3 \mathrm{~m}$ ecotone because natural shorelines preserve intertidal areas and planktivores have been shown to feed preferentially on intertidal zooplankton assemblages (David et al. 2016). Some planktivores - specifically, Menidia spp. in our study - also rely on wetland shorelines for spawning and nursery habitat (Balouskus \& Targett 2012). Finally, littoral-demersal species had high biomass along riprap shorelines relative to wetlands within $3 \mathrm{~m}$ from shore (about $47 \%$ of the mean biomass observed at wetlands) but not within $16 \mathrm{~m}$ from shore (about 13\%). This suggests the larger littoral-demersal individuals that utilize riprap habitat do not often venture outside of the relative safety of the riprap itself, while the shallow, turbid, debris-rich waters along wetland shorelines support littoral-demersal species at much greater distances from shore.

Although our study focused on four distinct shoreline types, a number of prior studies have examined changes in fish and invertebrate communities along gradients of partially armored wetlands or beaches (e.g., Bilkovic and Mitchell 2013; Lowe and Peterson 2014; Heerhartz et al. 2015). For example, Lowe and Peterson (2014) described decreasing abundances of three key fish species along a gradient of natural, partially urbanized (i.e., fragmented and hardened), and completely urbanized wetlands, with stronger effects of urbanization on resident species compared to transient species. Several studies have shown living shorelines, which combine wetland plants with a hardened structure, to be more similar to native wetlands than to riprap revetments; living shorelines are therefore considered less harmful than conventional coastal protection methods like bulkhead and riprap and as a result are becoming more widespread (Davis et al. 2008; Currin et al. 2010; Balouskus and Targett 2016; Bilkovic et al. 2016; Gittman et al. 2016b). Greater nekton diversity has also been detected at living shorelines relative to native wetlands, 
likely due to the diversity of shoreline habitat (Partyka and Peterson 2008; Peters et al. 2015). Our results suggest living shorelines may have different effects on different functional groups or size classes, meriting additional research.

Taxonomic distinctness and taxonomic variation of assemblages that included both fish and crustaceans indicated natural shoreline types had more diverse assemblages, especially within $3 \mathrm{~m}$ from shore, although relationships between taxonomic distinctness, variation and shoreline type were weak overall. Taxonomic distinctness patterns across shoreline type were similar for all species and finfish-only analyses at $3 \mathrm{~m}$ from shore, where low taxonomic distinctness at beaches may have reflected a lack of water depth relative to bulkhead and riprap (this study), and less subtidal structure relative to wetlands (Bilkovic and Roggero 2008). Taxonomic distinctness was greater at natural shorelines than hardened shorelines within $16 \mathrm{~m}$ of shore for both analyses, but the magnitude of the difference was greater for all species (1.7 units greater on average) than for finfish only ( 0.8 units greater). This difference is likely driven by the exclusion of grass shrimp, a littoral-demersal species that strongly associates with natural shorelines, from the finfish only analysis. Taxonomic variation was higher for all species along wetland shorelines within $3 \mathrm{~m}$ from shore, likely due to the influence of grass shrimp. Importantly, taxonomic variation was still higher along natural shorelines than hardened shorelines within $3 \mathrm{~m}$ from shore even for the finfish-only analysis. Average-to-high values of taxonomic diversity combined with high values of taxonomic variation, as observed for natural shorelines within $3 \mathrm{~m}$ from shore for all species and finfish, typically indicate more pristine locations (Clarke and Warwick et al. 2001). Furthermore, taxonomic variation measures complexity and low values, as observed for hardened shoreline types in our study within $3 \mathrm{~m}$ from shore, may indicate environmental disturbance (Yang et al. 2016). The differences in taxonomic distinctness and variation within $3 \mathrm{~m}$ from shore contrast their relative consistency within $16 \mathrm{~m}$ from shore, and underscore the other strong effects of hardened shorelines on fauna documented by our study within extreme nearshore interface zones.

\section{Conclusion-Management Considerations}

Management applications from our results include considering species-specific or functional-group-specific responses and placing the effects of shoreline hardening into a wholesystem context. We provide clear evidence that shoreline types can affect different functional groups in different ways. Although our study focused on the Chesapeake Bay, responses of specific species were generally similar to the response of their respective functional group (Tables 3 and 4). Since the functional groups represented in our study are prevalent in estuaries worldwide, our results may be broadly applicable to other systems. Based on our findings, it appears that one of the largest effects of shoreline hardening is the alteration of shallow waters at the interface between land and water. These extreme nearshore interface areas, represented in this study by waters within $3 \mathrm{~m}$ from shore, tend to be deeper at hardened shorelines than at natural shoreline. Differences in water depth, environmental characteristics, and food availability between natural and hardened shorelines likely contributed to our observed functional group and sizeclass-specific patterns, and should be considered when making management decisions.

Although this study focused on local-scale effects, systemscale effects may also be important. One major finding of this study is that natural shorelines serve as critically important habitat for resident littoral-demersal species and for juveniles of species from other functional groups. As such, natural shorelines, especially wetlands, are substantially integrated components of larger systems (e.g., Childers et al. 2000; Weinstein et al. 2005), as nursery ground production often moves across habitats and ecosystems (Kneib 1997; Sheaves et al. 2015). Furthermore, whole-system production in coastal estuaries is strongly tied to overall production - including resident species - in intertidal wetlands (Teal 1962; Kneib 1997; Weinstein et al. 2014), and many marine transient species benefit from wetland shorelines and their production without directly occupying those habitats (Litvin and Weinstein 2003; Weinstein et al. 2005). Therefore, shoreline hardening that comes at the expense of wetland habitat likely reduces estuarine production. Given this, it is not surprising that hardened shorelines and wetland loss appear to have cumulative effects on abundance of a variety of fish and crustacean taxa in estuaries (Peterson and Lowe 2009; Dethier et al. 2016; Kornis et al. 2017). Fortunately, high ecosystem productivity, such as when the majority of a subestuary is wetland habitat, can overcome small-scale negative effects of shoreline hardening on infauna, and thus may be important to resilience against shoreline alteration (Lawless and Seitz 2014). We join others (e.g., Weinsten and Litvin 2016) in suggesting a whole-system approach to shoreline management to ensure increased coastal protection needs are met in ways that best maintain healthy estuaries and the ecosystem services they provide.

Acknowledgements We thank H. Soulen, K. Heggie, K. Evans, C. Hause, C. Kliewer, M. Odabaș-Geldiay, D. Shikashio, J. Wilhelm, and many others for help with field collections. We also thank the NOAA Chesapeake Bay Office (Annapolis, MD) for leveraged, in-kind support for field collections, specifically the use of a specially designed skiff and associated equipment, supplies, and personnel. Scientific collection permits were obtained from the Maryland and Virginia Departments of Natural Resources prior to sampling, and animal handling conformed to the Smithsonian Environmental Research Center's animal care protocols. Mention of specific product or trade names does not constitute endorsement by the U.S. Government. This is publication \#17-012 of the NOAA/ CSCOR Mid-Atlantic Shorelines project, grant number NA09NOS4780214. 
Open Access This article is distributed under the terms of the Creative Commons Attribution 4.0 International License (http://creativecommons. org/licences/by/4.0/), which permits use, duplication, adaptation, distribution and reproduction in any medium or format, as long as you give appropriate credit to the original author(s) and the source, provide a link to Creative Commons license and indicate if changes were made.

\section{References}

Abadie, A. 2002. Bootstrap tests for distributional treatment effects in instrumental variable models. Journal of the American Statistical Association 97: 284-292.

Able, K.W., D.M. Nemerson, R. Bush, and P. Light. 2001. Spatial variation in Delaware Bay (USA) marsh creek fish assemblages. Estuaries 24: 441-452.

Able, K.W., T.M. Grothues, J. Turnure, D.M. Byrne, and P. Clerkin. 2012. Distribution, movements, and habitat use of small Striped Bass (Morone saxatilis) across multiple spatial scales. Fishery Bulletin 110: 176-192.

Akin, S., K.O. Winemiller, and F.P. Gelwick. 2003. Seasonal and spatial variations in fish and macrocrustacean assemblage structure in Mad Island Marsh estuary, Texas. Estuarine, Coastal and Shelf Science 57: 269-282.

Angermeier, P.L., and M.R. Winston. 1999. Characterizing fish community diversity across Virginia landscapes: prerequisite for conservation. Ecological Applications 9: 335-349.

Arkema, K.K., G. Gaunnel, G. Verutes, S.A. Wood, A. Guerry, M. Ruckelshaus, P. Kareiva, M. Lacayo, and J.M. Silver. 2013. Coastal habitats shield people and property from sea-level rise and storms. Nature Climate Change 3: 913-918.

Balouskus, R.G., and T.E. Targett. 2012. Egg deposition by Atlantic silverside, Menidia menidia: Substrate utilization and comparison of natural and altered shoreline type. Estuaries and Coasts 35: $1100-1109$.

Balouskus, R.G., and T.E. Targett. 2016. Fish and blue crab density along a riprap-sill hardened shoreline: comparisons with Spartina marsh and riprap. Transactions of the American Fisheries Society 145: 776-773.

Barbier, E.B., S.D. Hacker, C. Kennedy, E.W. Koch, A.C. Stier, and B.R. Silliman. 2011. The value of estuarine and coastal ecosystem services. Ecological Monographs 81: 169-193.

Beck, M.W., K.L. Heck Jr., K.W. Able, D.L. Childers, D.B. Eggleston, B.M. Gillanders, B. Halpern, C.G. Hays, K. Hoshino, T.J. Minello, R.J. Orth, P.F. Sheridan, and M.P. Weinstein. 2001. The identification, conservation, and management of estuarine and marine nurseries for fish and invertebrates. Bioscience 51: 633-641.

Becker, A., and I.M. Suthers. 2014. Predator driven diel variation in abundance and behaviour of fish in deep and shallow habitats of an estuary. Estuarine, Coastal and Shelf Science 144: 82-88.

Bilkovic, D.M., and M.M. Mitchell. 2013. Ecological tradeoffs of stabilized salt marshes as a shoreline protection strategy: effects of artificial structures on macrobenthic assemblages. Ecological Engineering 61: 469-481.

Bilkovic, D.M., and M.M. Roggero. 2008. Effects of coastal development on nearshore estuarine nekton communities. Marine Ecology Progress Series 358: 27-39.

Bilkovic, D.M., M. Roggero, C.H. Hershner, and K.H. Havens. 2006. Influence of land use on macrobenthic communities in nearshore estuarine habitats. Estuaries and Coasts 29: 1185-1195.

Bilkovic, D.M., M.M. Mitchell, P. Mason, and K. Durhing. 2016. The role of living shorelines as estuarine habitat conservation strategies. Coastal Management 44: 161-174.
Borcard, D., P. Legendre, and P. Drapeau. 1992. Partialling out the spatial component of ecological variation. Ecology 73: 1045-1055.

Brody, S.D., S.E. Davis III, W.E. Highfield, and S. Bernhardt. 2008. A spatio-temporal analysis of Section 404 wetland permitting in Texas and Florida: thirteen years of impact along the coast. Wetlands 28: 107-116.

Bulleri, F., and M.G. Chapman. 2010. The introduction of coastal infrastructure as a driver of change in marine environments. Journal of Applied Ecology 47: 26-35.

Childers, D.L., J.W. Day Jr., and H.N. Mckellar Jr. 2000. Twenty more years of marsh and estuarine flux studies: revisiting Nixon (1980). In Concepts and Controversies in Tidal Marsh Ecology, ed. M.P. Weinstein and D.A. Kreeger, 391-424. Dordrecht: Kluwer Academic.

Clark, K.R., and R.M. Warwick. 1998. A taxonomic distinctness index and its statistical properties. Journal of Applied Ecology 35: 523 531.

Clark, K.R., and R.M. Warwick. 1999. The taxonomic distinctness measure of biodiversity: weighting of step lengths between hierarchical level. Marine Ecology Progress Series 184: 21-29.

Clark, K.R., and R.M. Warwick. 2001. A further biodiversity index applicable to species lists: variation in taxonomic distinctness. Marine Ecology Progress Series 216: 265-278.

Crossett, K., T. Culliton, P. Wiley, and T. Goodspeed. 2004. Population trends along the coastal United States, 1980-2008. Silver Spring: National Oceanic and Atmospheric Administration.

Currin, C. A., W. S. Chappell, and A. Deaton. 2010. Developing alternative shoreline armoring strategies: the living shoreline approach in North Carolina. In Puget sound shorelines and the impacts of armoring, ed. H. Shipman, M. N. Dethier, G. Gelfenbaum, K. L. Fresh, and R. S. Dinicola, 91-102. U.S. Geological Survey Scientific Investigations Report 2010-5254.

Davias, L.A., M.S. Kornis, and D.L. Breitburg. 2014. Environmental factors influencing $\delta 13 \mathrm{C}$ and $\delta 15 \mathrm{~N}$ in three fishes from Chesapeake Bay. ICES Journal of Marine Science 71: 689-702.

David, V., J. Selleslagh, A. Nowaczyk, S. Dubois, G. Bachelet, H. Blanchet, B. Gouillieux, N. Lavesque, M. Leconte, N. Savoye, B. Sautour, and J. Lobry. 2016. Estuarine habitats structure zooplankton communities: implications for the pelagic trophic pathways. Estuarine, Coastal and Shelf Science. doi:10.1016/j. ecss.2016.01.022.

Davis, J. L. D., R. L. Takacs, and R. Schnabel. 2008. Evaluating ecological impacts of living shorelines and shoreline habitat elements: an example from the upper western Chesapeake Bay. In Management, policy, science, and engineering of nonstructural erosion control in the Chesapeake Bay: proceedings of the 2006 living shoreline summit, ed. S. Y. Erdle, J. L. D. Davis, and K. G. Sellner, 55-61. Chesapeake Research Consortium, Publication 08-164, Gloucester Point.

Dethier, M.N., W.W. Raymond, A.N. McBride, J.D. Toft, J.R. Cordell, A.S. Ogston, S.M. Heerhartz, and H.D. Berry. 2016. Multiscale impacts of armoring on Salish Sea shorelines: Evidence for cumulative and threshold effects. Estuarine, Coastal and Shelf Science 175: 106-117.

Dugan, J.E., L. Airoldi, M.G. Chapman, S.J. Walker, and T. Schlacher. 2011. Estuarine and coastal structures: environmental effects, a focus on shore and nearshore structures. In Treatise on Estuarine and Coastal Science, ed. E. Wolanski and D.S. Mclusky, vol. Vol. 8, 1741. Waltham: Academic Press.

Ellingsen, K.E., K.R. Clarke, P.J. Somerfield, and R.M. Warwick. 2005. Taxonomic distinctness as a measure of diversity applied over a large scale: the benthos of the Norwegian continental shelf. Journal of Animal Ecology 74: 1069-1079.

Gedan, K.B., B.R. Silliman, and M.D. Bertness. 2009. Centuries of human-driven change in salt marsh ecosystems. Annual Review of Marine Science 1: 117-141. 
Gittman, R.K., F.J. Fodrie, A.M. Popowich, D.A. Keller, J.F. Bruno, C.A. Currin, C.H. Peterson, and M.F. Piehler. 2015. Engineering away our natural defenses: an analysis of shoreline hardening in the US. Frontiers in Ecology and the Environment 13: 301-307.

Gittman, R.K., S.B. Scyphers, C.S. Smith, I.P. Neylan, and J.H. Grabowski. 2016a. Ecological consequences of shoreline hardening: a meta-analysis. Bioscience 66: 763-773.

Gittman, R.K., C.H. Peterson, C.A. Currin, F.J. Fodrie, M.F. Piehler, and J.F. Bruno. 2016b. Living shorelines can enhance the nursery role of threatened estuarine habitats. Ecological Applications 26: 249-263.

Glasby, T.M., S.D. Connell, M.G. Holloway, and C.L. Hewitt. 2006. Nonindigenous biota on artificial structures: could habitat creation facilitate biological invasions? Marine Biology 151: 887-895.

Halpern, B.S., S. Walbridge, K.A. Selkoe, C.V. Kappel, F. Micheli, C. D’Agrosa, J.F. Bruno, K.S. Casey, C. Ebert, H.E. Fox, R. Fujita, D. Heinemann, H.S. Lenihan, E.M.P. Madin, M.T. Perry, E.R. Selig, M. Spalding, R. Steneck, and R. Watson. 2008. A global map of human impact on marine ecosystems. Science 319: 948-952.

Hartman, K.J., and S.B. Brandt. 1995. Trophic resource partitioning, diets, and growth of sympatric estuarine predators. Transactions of the American Fisheries Society 124: 520-537.

Heerhartz, S.M., and J.D. Toft. 2015. Movement patterns and feeding behavior of juvenile salmon (Oncorhynchus spp.) along armored and unarmored estuarine shorelines. Environmental Biology of Fishes 98: 1501-1511.

Heerhartz, S.M., J.D. Toft, J.R. Cordell, M.N. Dethier, and A.S. Ogston. 2015. Shoreline armoring in an estuary constrains wrack-associated invertebrate communities. Estuaries and Coasts 39: 171-188.

Hines, A.H., and G.M. Ruiz. 1995. Temporal variation in juvenile blue crab mortality: nearshore shallows and cannibalism in Chesapeake Bay. Bulletin of Marine Science 57: 884-901.

Hodson, R.G., J.O. Hackman, and C.R. Bennett. 1981. Food habits of young spots in nursery areas of the Cape Fear River Estuary, North Carolina. Transactions of the American Fisheries Society 110: 495501.

Kettenring, K.M., D.F. Whigham, E.L.G. Hazelton, S.K. Gallagher, and H.M. Baron. 2015. Biotic resistance, disturbance, and mode of colonization impact the invasion of a widespread, introduced, wetland grass. Ecological Applications 25: 466-480.

King, R.S., A.H. Hines, F.D. Craige, and S. Grap. 2005. Regional, watershed and local correlates of blue crab and bivalve abundances in subestuaries of Chesapeake Bay, USA. Journal of Experimental Marine Biology and Ecology 319: 101-116.

Kneib, R.T. 1997. The role of tidal marshes in the ecology of estuarine nekton. Oceanography and Marine Biology 35: 163-220.

Kornis, M.S., D. Breitburg, R. Balouskus, D.M. Bilkovic, L.A. Davias, S. Giordano, K. Heggie, A.H. Hines, J.M. Jacobs, T.E. Jordan, R.S. King, C.J. Patrick, R.D. Seitz, H. Soulen, T.E. Targett, D. E. Weller, D.F. Whigham, and J. Uphoff Jr. 2017. Linking the abundance of estuarine fish and crustaceans in nearshore waters to shoreline hardening and landcover. Estuaries and Coasts. doi:10.1007/s12237017-0213-6

Lawless, A.S., and R.D. Seitz. 2014. Effects of shoreline stabilization and environmental variables on benthic infaunal communities in the Lynnhaven River System of Chesapeake Bay. Journal of Experimental Marine Biology and Ecology 457: 41-50.

Leonard, D.R.P., K.R. Clarke, P.J. Somerfield, and R.M. Warwick. 2006. The application of an indicator based on taxonomic distinctness for UK marine biodiversity assessments. Journal of Environmental Management 78: 52-62.

Litvin, S.Y., and M.P. Weinstein. 2003. Life history strategies of estuarine nekton: the role of marsh macrophytes, benthic microalgae, and phytoplankton in the trophic spectrum. Estuaries 26: 552-562.

Lotze, H.K., et al. 2006. Depletion, degradation, and recovery potential of estuaries and coastal seas. Science 312: 1806-1809.
Lowe, M.R., and M.S. Peterson. 2014. Effects of coastal urbanization on salt-marsh faunal assemblages in the northern Gulf of Mexico. Marine and Coastal Fisheries: Dynamics, Management, and Ecosystem Science 6: 89-107.

Lowe, M.R., and M.S. Peterson. 2015. Body condition and foraging patterns of nekton from salt marsh habitats arrayed along a gradient of urbanization. Estuaries and Coasts 38: 800-812.

McCormick, M.K., K.M. Kettenring, H.M. Baron, and D.F. Whigham. 2010. Spread of invasive Phragmites australis in estuaries with differing degrees of development: genetic patterns, Allee effects and interpretation. Journal of Ecology 98: 1369-1378.

Minello, T.J., K.W. Able, M.P. Weinstein, and C.G. Hays. 2003. Salt marshes as nurseries for nekton: testing hypotheses on density, growth and survival through meta-analysis. Marine Ecology Progress Series 246: 39-59.

Munsch, S.H., J.R. Cordell, and J.D. Toft. 2015. Effects of shoreline engineering on shallow subtidal fish and crab communities in an urban estuary: A comparison of armored shorelines and nourished beaches. Ecological Engineering 81: 312-320.

Munsch, S.H., J.R. Cordell, and J.D. Toft. 2016. Fine-scale habitat use and behaviour of a nearshore fish community: nursery functions, predation avoidance, and spatiotemporal habitat partitioning. Marine Ecology Progress Series 557: 1-15.

Murdy, E.O., R. S. Birdsong, and J. A. Musick. 1997. Fishes of Chesapeake Bay, 324. Washington: Smithsonian Institution Press.

Nemerson, D.M., and K.W. Able. 2003. Spatial and temporal patterns in the distribution and feeding habits of Morone saxatilis in marsh creeks of Delaware Bay, USA. Fisheries Management and Ecology 10: 337-348.

Nemerson, D.M., and K.W. Able. 2004. Spatial patterns in diet and distribution of juveniles of four fish species in Delaware Bay marsh creeks: factors influencing fish abundance. Marine Ecology Progress Series 276: 249-262.

Ng, C.L., K.W. Able, and T.M. Grothues. 2007. Habitat use, site fidelity, and movement of adult striped bass in a southern New Jersey estuary based on mobile acoustic telemetry. Transactions of the American Fisheries Society 136: 1344-1355.

Partyka, M.L., and M.S. Peterson. 2008. Habitat quality and salt-marsh species assemblages along an anthropogenic estuarine landscape. Journal of Coastal Research 24: 1570-1581.

Patrick, C.J., D.E. Weller, X. Li, and M. Ryder. 2014. Effects of shoreline alteration and other stressors on submerged aquatic vegetation in subestuaries of Chesapeake Bay and the Mid-Atlantic Coastal Bays. Estuaries and Coasts 37: 1516-1531.

Patrick, C.J., D.E. Weller, and M. Ryder. 2016. The relationship between shoreline armoring and adjacent submerged aquatic vegetation in Chesapeake Bay and nearby Atlantic Coastal Bays. Estuaries and Coasts 39: 158-170.

Patterson, A.W., and A.K. Whitfield. 2000. Do shallow-water habitats function as refugia for juvenile fishes? Estuarine, Coastal and Shelf Science 51: 359-364.

Peters, J.R., L.A. Yeager, and C.A. Layman. 2015. Comparison of fish assemblages in restored and natural mangrove habitats along an urban shoreline. Bulletin of Marine Science 91: 125-139.

Peterson, M.S., and M.R. Lowe. 2009. Implications of cumulative impacts to estuarine and marine habitat quality for fish and invertebrate resources. Reviews in Fisheries Science 17: 505-523.

Peterson, M.S., B.H. Comyns, J.R. Hendon, P.J. Bond, and G.A. Duff. 2000. Habitat use by early life-history stages of fishes and crustaceans along a changing estuarine landscape: Differences between natural and altered shoreline sites. Wetlands Ecology and Management 8: 209-219.

Rahmstorf, S. 2007. A semi-empirical approach to projecting future sealevel rise. Science 315: 368-370.

Ross, S.W. 2003. The relative value of different estuarine nursery areas in 
North Carolina for transient juvenile marine fishes. Fishery Bulletin 101: 384-404.

Rozas, L.P., T.J. Minello, R.J. Zimmerman, and P. Caldwell. 2007. Nekton populations, long term wetland loss, and the effect of recent habitat restoration in Galveston Bay, Texas, USA. Marine Ecology Progress Series 344: 119-130.

Ruiz, G.M., A.H. Hines, and M.H. Posey. 1993. Shallow water as a refuge habitat for fish and crustaceans in non-vegetated estuaries: an example from Chesapeake Bay. Marine Ecology Progress Series 99: 1-16.

Sciance, M.B., C.J. Patrick, D.E. Weller, M.N. Williams, M.K. McCormick, and E.L. Hazelton. 2016. Local and regional disturbances associated with the invasion of Chesapeake Bay marshes by the common reed Phragmites australis. Biological Invasions. doi:10.1007/s10530-016-1136-z.

Seitz, R.D., R.N. Lipcius, N.H. Olmstead, M.S. Seebo, and D.M. Lambert. 2006. Influence of shallow-water habitats and shoreline development on abundance, biomass, and diversity of benthic prey and predators in Chesapeake Bay. Marine Ecology Progress Series 326: $11-27$

Sekhon, J.S. 2011. Multivariate and propensity score matching software with automated balance optimization. Journal of Statistical Software 42: $1-52$.

Sharma, S., P. Legendre, M. De Cáceres, and D. Boisclair. 2011. The role of environmental and spatial processes in structuring native and nonnative fish communities across thousands of lakes. Ecography 34: $762-771$.

Sheaves, M., R. Baker, I. Nagelkerken, and R.M. Connolly. 2015. True value of estuarine and coastal nurseries for fish: Incorporating complexity and dynamics. Estuaries and Coasts 38: 401-414.

Sobocinski, K.L., J.R. Cordell, and C.A. Simenstad. 2010. Effects of shoreline modifications on supratidal macroinvertebrate fauna on Puget Sound, Washington beaches. Estuaries and Coasts 33: 699711.

Strayer, D.L., S.E.G. Findlay, D. Miller, H.M. Malcom, D.R. Fischer, and T.
Coote. 2012. Biodiversity in Hudson River shore zones: influence of shoreline type and physical structure. Aquatic Sciences 74: 597-610.

Tan, E.L.-Y., M. Mayer-Pinto, E.L. Johnston, and K.A. Dafforn. 2015. Differences in intertidal microbial assemblages on urban structures and natural rocky reef. Frontiers in Microbiology 6: 1276. doi:10.3389/fmicob.2015.01276.

Teal, J.M. 1962. Energy flow in the salt marsh ecosystem of Georgia. Ecology 43: 614-624.

Toft, J.D., J.R. Cordell, C.A. Simenstad, and L.A. Stamatiou. 2007. Fish distribution, abundance, and behavior along city shoreline types in Puget Sound. North American Journal of Fisheries Management 27: 465-480.

Tuckey, T.D., and M.C. Fabrizio. 2013. Influence of survey design on fish assemblages: implications from a study in Chesapeake Bay tributaries. Transactions of the American Fisheries Society 142: 957973.

Vaselli, S., F. Bulleri, and L. Benedetti-Cecchi. 2008. Hard coastaldefence structures as habitats for native and exotic rock-bottom species. Marine Environmental Research 66: 395-403.

Weinstein, M.P., S.Y. Litvin, and V.G. Guida. 2005. Considerations of habitat linkages, estuarine landscapes, and the trophic spectrum in wetland restoration design. Journal of Coastal Research SI40: 5163.

Weinstein, M.P., S.Y. Litvin, and V.G. Guida. 2010. Stable isotope and biochemical composition of white perch in a Phragmites dominated salt marsh and adjacent waters. Wetlands 30: 1181-1191.

Weinstein, M.P., S.Y. Litvin, and J.M. Krebs. 2014. Restoration ecology: Ecological fidelity, restoration metrics, and a systems perspective. Ecological Engineering 65: 71-87.

Weinsten, M.P., and S.Y. Litvin. 2016. Macro-Restoration of tidal wetlands: a whole estuary approach. Ecological Restoration 34: 27-38.

Yang, M. L., W. S. Jiang, W. Y. Wang, X. F. Pan, D. P. Kong, F. H. Han, X. Y. Chen, and J. X. Yang. 2016. Fish assemblages and diversity in three tributaries of the Irrawaddy River in China: changes, threats and conservation perspectives. Knowledge \& Management of Aquatic Ecosystems 417. doi: 10.1051/kmae/2015042. 